\title{
Catalytic removal of volatile organic compounds using ordered porous transition metal oxide and supported noble metal catalysts
}

\author{
Yuxi Liu, Jiguang Deng, Shaohua Xie, Zhiwei Wang, Hongxing Dai* \\ Beijing Key Laboratory for Green Catalysis and Separation, Key Laboratory of Beijing on Regional Air Pollution Control, Key Laboratory of Advanced \\ Functional Materials, Education Ministry of China, and Laboratory of Catalysis Chemistry and Nanoscience, College of Environmental and Energy \\ Engineering, Beijing University of Technology, Beijing 100124, China
}

\section{A R T I C L E I N F O}

Article history:

Received 31 March 2016

Accepted 3 May 2016

Published 5 August 2016

Keywords:

Volatile organic compound

Catalytic combustion

Porous transition metal oxide

Perovskite-type oxide

Supported noble metal catalyst

\begin{abstract}
A B S T R A C T
Most of volatile organic compounds (VOCs) are harmful to the atmosphere and human health. Catalytic combustion is an effective way to eliminate VOCs. The key issue is the availability of high performance catalysts. Many catalysts including transition metal oxides, mixed metal oxides, and supported noble metals have been developed. Among these catalysts, the porous ones attract much attention. In this review, we focus on recent advances in the synthesis of ordered mesoporous and macroporous transition metal oxides, perovskites, and supported noble metal catalysts and their catalytic oxidation of VOCs. The porous catalysts outperformed their bulk counterparts. This excellent catalytic performance was due to their high surface areas, high concentration of adsorbed oxygen species, low temperature reducibility, strong interaction between noble metal and support and highly dispersed noble metal nanoparticles and unique porous structures. Catalytic oxidation of carbon monoxide over typical catalysts was also discussed. We made conclusive remarks and proposed future work for the removal of VOCs.
\end{abstract}

(C) 2016, Dalian Institute of Chemical Physics, Chinese Academy of Sciences. Published by Elsevier B.V. All rights reserved.

\section{Introduction}

Volatile organic compounds (VOCs) have a high vapor pressure and low water solubility and most of them are major contributors to air pollution due to their toxic nature or as a precursor of ozone or photochemical smog [1,2]. A large variety of VOCs are emitted from industrial and transportation (outdoor sources) and household (indoor sources) activities, such as power generation, vehicle emission, solvent use, and from office supplies and restaurant and domestic cooking. Most VOCs are harmful to the atmosphere and human beings $[3,4]$. VOCs include alkanes, olefins, alcohols, ketones, aldehydes, aromat- ics, paraffins, and halogenated hydrocarbons [5]. Among the most common and toxic VOCs are formaldehyde, benzene, toluene, propene, phenol, and acetone.

The removal of these emitted VOCs is a crucial topic in environmental protection. The conventional approach to dispose of highly concentrated VOC streams is thermal incineration. However, this needs to be operated at high temperatures $\left(800-1200{ }^{\circ} \mathrm{C}\right.$ ) and requires a high operating cost. Furthermore, undesirable byproducts such as nitrogen oxides are produced in the incineration. In contrast, catalytic combustion or oxidation is an effective and feasible technology for VOC removal, which can be operated with dilute VOC effluent

\footnotetext{
* Corresponding author. Tel: +86-10-67396118; Fax: +86-10-67391983; E-mail: hxdai@bjut.edu.cn

This work was supported by the National High Technology Research and Development Program (863 Program, 2015AA034603), the National Natural Science Foundation of China (21377008, 201077007, 20973017), Foundation on the Creative Research Team Construction Promotion Project of Beijing Municipal Institutions, and Scientific Research Base Construction-Science and Technology Creation Platform National Materials Research Base Construction. 
streams $(<1 \%)$ and at low temperatures $\left(<600^{\circ} \mathrm{C}\right)$. Thus, this has been widely investigated in recent years. Current efforts for this technology concentrate on developing efficient and low cost catalysts which can catalyze the complete oxidation of VOCs into $\mathrm{CO}_{2}$ and $\mathrm{H}_{2} \mathrm{O}$ at low temperatures [6]. Two classes of catalysts, supported noble metals and transition metal oxides (TMOs), are the most promising materials for VOC combustion [7-11]. Supported noble metal catalysts, in spite of their more expensive costs, are preferred because of their high specific activities at low temperatures [12-18]. Regarding metal oxide catalysts, pure transition metal oxides, mixed transition metal oxides, and perovskites are recognized as efficient low cost catalysts for VOCs combustion [19-28].

It is accepted that the catalytic activity of a metal oxide is associated with its surface area, pore structure, oxygen nonstoichiometry, and reducibility [29]. These factors are determined by the preparation method. The preservation of high surface area is critical because the reaction rate is proportional to the surface area [30]. A good approach for increasing the surface area is to have a metal oxide material fabricated as an ordered porous structure. Porous materials are classified into three types in terms of the pore diameter: microporous (below $2 \mathrm{~nm}$ ), mesoporous (2-50 nm), and macroporous (above 50 $\mathrm{nm}$ ) [31]. The fabrication of porous materials, especially the creation of ordered meso- or macroporous materials, has been extensively investigated in the past years. Template methods, which imply a more or less direct replication of the pore system from the template, is one promising synthetic pathways to create porous materials, especially ordered porous materials [32].

The preparation of transition metal oxides by nanocasting procedures makes it possible to obtain nanopore-structured materials which are difficult to achieve using surfactant-usage techniques. This constitutes an additional advantage of the hard template route over the soft template route [33]. The first nanopore-structured transition metal oxide synthesized with mesostructured silica materials was $\mathrm{Cr}_{2} \mathrm{O}_{3}$ using SBA-15 as template [34]. Tian and coworkers obtained nanospheres of $\mathrm{In}_{2} \mathrm{O}_{3}$ and $\mathrm{Co}_{3} \mathrm{O}_{4}$ prepared from 3D-caged mesoporous silica (SBA-16) that showed ordered patterns in TEM images [35]. Nanopore-structured $\mathrm{CeO}_{2}$ with a BET surface area of $198 \mathrm{~m}^{2} / \mathrm{g}$ was prepared using a KIT-6 silica as template by Laha et al. [36]. Recently, Guan and coworkers [37] reported a general reaction container effect in the nanocasting synthesis of a series of mesoporous metal oxides.

Mesopores and micropores help to impart a high surface area and pore volume in a material. They provide numerous active sites and size selectivity for molecules. These small pores can then be coupled with larger macropores that improve mass transfer through the structure to overcome the diffusion limitation present in purely micro-/mesoporous materials. Novel approaches for the synthesis of hierarchically functional materials have been developed in recent years. One such class of materials are the three dimensionally ordered macroporous (3DOM) solids. The general process of fabricating 3DOM structures is simple: (1) form a colloidal crystal of close packed spheres with a uniform size; (2) fill the interstitial space with a fluid precursor capable of solidification, and (3) remove the template to obtain a porous inverse replica [38]. The colloidal crystal templates used for the generation of 3DOM materials were prepared from monodispersed silica or polymer spheres, including polystyrene (PS) and poly(methyl methacrylate) (PMMA). The spheres can be arranged into close packed structures by several methods [39]. For example, using metal nitrates or acetates as precursor and well-aligned PMMA or PS microspheres as the hard template, 3DOM-structured $\mathrm{La}_{1-x} \mathrm{Sr}_{x} \mathrm{FeO}_{3}$ (surface area 24-49 m²/g) [40], $\mathrm{LaMnO}_{3}$ [41], and $\mathrm{La}_{0.7} \mathrm{Ca}_{0.3-} \mathrm{Sr}_{x} \mathrm{MnO}_{3}$ (surface area $24 \mathrm{~m}^{2} / \mathrm{g}$ ) [42] were prepared. Zhao and coworkers adopted PMMA as the template to generate 3DOM-structured $\mathrm{LaFeO}_{3}$-supported $\mathrm{Au}$ (surface area 32 $\mathrm{m}^{2} / \mathrm{g}$ ) [43], $\mathrm{Ce}_{0.8} \mathrm{Zr}_{0.2} \mathrm{O}_{2}$-supported $\mathrm{Au}$ (surface area $58 \mathrm{~m}^{2} / \mathrm{g}$ ) [44] and $\mathrm{LaCo}_{x} \mathrm{Fe}_{1-x} \mathrm{O}_{3}(x=0-0.5)$ [45] catalysts, which showed superior performance for the catalytic oxidation of soot. In the past years, Dai's group has investigated the controlled preparation and physicochemical properties of porous $\mathrm{Co}_{3} \mathrm{O}_{4}[46,47]$, $\mathrm{MnO}_{x}[46,48], \mathrm{Cr}_{2} \mathrm{O}_{3}$ [49,50], $\mathrm{Fe}_{2} \mathrm{O}_{3}$ [51], $\gamma-\mathrm{Al}_{2} \mathrm{O}_{3}$ [52], $\mathrm{LaMnO}_{3}$ [53,54,55], $\mathrm{LaCoO}_{3}$ [56], $\mathrm{La}_{2} \mathrm{CuO}_{4}$ [57], $\mathrm{InVO}_{4}$ [58], $\mathrm{SrFeO}_{3-\delta}$ [59], and $\mathrm{BiVO}_{4}$ [60] using the silica-templating or surfactant-assisted PMMA-templating strategy. These authors pointed out that the good catalytic performance of the materials obtained for VOC combustion was associated with the large surface area and unique pore structure.

In this review, the correlation between surface area, pore structure, metal dispersion and catalytic performance of the porous materials that leads to the identification of the catalytic active sites is discussed. Due to the explosion of the publications in this field and limited by space, only two kinds of ordered porous materials associated with the issue of VOC combustion are discussed: (1) ordered mesoporous transition metal oxide (TMOs) and supported noble metal catalysts; and (2) ordered macroporous transition metal oxide (TMOs) and supported noble metal catalysts.

\section{Recent advances in the synthesis and application of ordered porous transition metal oxides and supported noble metal catalysts}

\subsection{Ordered mesoporous transition metal oxide catalysts}

The utilization of mesoporous TMOs as the catalyst for VOC combustion has attracted attention in the past years because of their low cost, stable structure and, especially, excellent catalytic performance. Great achievements have so far been obtained [61-63].

Compositionally identical TMOs with different pore structures have been reported in the literature. For example, one dimensional (1D)- $\mathrm{MnO}_{2}$, two dimensional (2D)- $\mathrm{MnO}_{2}$ and three dimensional (3D)- $\mathrm{MnO}_{2}$ with different structures were synthesized using the hydrothermal and nanocasting methods, respectively. The catalytic activity for ethanol oxidation over different $\mathrm{MnO}_{2}$ catalysts decreased in the order of $3 \mathrm{D}-\mathrm{MnO}_{2}>$ $2 \mathrm{D}-\mathrm{MnO}_{2}>1 \mathrm{D}-\mathrm{MnO}_{2}$. The apparent activation energy over $3 \mathrm{D}-\mathrm{MnO}_{2}$ was the lowest $(28.2 \mathrm{~kJ} / \mathrm{mol})$, which was much lower than over $2 \mathrm{D}-\mathrm{MnO}_{2}(33.6 \mathrm{~kJ} / \mathrm{mol})$ and $1 \mathrm{D}-\mathrm{MnO}_{2}(52.8 \mathrm{~kJ} / \mathrm{mol})$. A mesoporous $\mathrm{MnO}_{2}$ catalyst, especially $3 \mathrm{D}-\mathrm{MnO}_{2}$, had the best 
low temperature catalytic activity, which was primarily due to the better low temperature reducibility, more adsorbed surface oxygen species and $\mathrm{Mn}^{4+}$ ions [64]. In addition, Puertolas et al. [65] demonstrated that the aging temperature of the silica template was of great importance as this parameter was directly responsible for both the pore size and surface area of the catalysts. For the nanocast $\mathrm{CeO}_{2}$ catalysts, the one prepared from the silica template aged at $80{ }^{\circ} \mathrm{C}$ presented the highest activity for naphthalene oxidation. The best catalyst gave a $\mathrm{CO}_{2}$ yield of over $80 \%$ at $260{ }^{\circ} \mathrm{C}$ and over $95 \%$ at $275{ }^{\circ} \mathrm{C}$. However, Garcia et al. [66] found that the relationship between the ordered structure and high catalytic activity for propane and toluene oxidation was reversed. The partially ordered $\mathrm{Co}_{3} \mathrm{O}_{4}$ showed a higher reaction rate when normalized per surface area than the fully ordered replicas. Since the reducibility was not very different among the porous catalysts, the different activity can be related to the existence of a higher concentration of highly reactive oxygen defects (higher concentration of surface $\mathrm{Co}^{2+}$ species) in the partly ordered catalysts [66]. In fact, for catalytic oxidation, CO oxidation is one of the most studied reaction using nanocast catalysts. The catalytic activity was also dependent on the textural parameters of the catalysts. A better performance was achieved over the catalyst with a higher surface area and more open pore system. By varying the hydrothermal temperature of the KIT-6 synthesis, two kinds of $\mathrm{Co}_{3} \mathrm{O}_{4}$ replicas possessing coupled and uncoupled sub-frameworks were obtained. $\mathrm{Co}_{3} \mathrm{O}_{4}$ replicas with uncoupled sub-frameworks which possessed a higher surface area and more open pore system exhibited better performance than $\mathrm{Co}_{3} \mathrm{O}_{4}$ replicas with coupled sub-frameworks [67].

Dai and coworkers have developed a novel solvent-free route using KIT- 6 as hard template to synthesize $\mathrm{Cr}_{2} \mathrm{O}_{3}$ with ordered 3D hexagonal polycrystalline structures in an autoclave. They believed that the co-existence of multiple chromium species promoted the low temperature reducibility of chromia, thus increasing the catalytic performance for the oxidation of toluene and ethyl acetate [49]. 3D ordered mesoporous cubic $\mathrm{Co}_{3} \mathrm{O}_{4}$ (Co-KIT6 and Co-SBA16) were also fabricated using the KIT-6- and SBA-16-templating methods, respectively. It is shown that the $\mathrm{Co}_{3} \mathrm{O}_{4}$ prepared possessed a large surface area (118-121 $\mathrm{m}^{2} / \mathrm{g}$ ), high adsorbed oxygen species concentration, and good low temperature reducibility. Over the Co-KIT6 catalyst at a space velocity of $20000 \mathrm{~mL} /(\mathrm{g} \mathrm{h}), 90 \%$ toluene and methanol conversions were achieved at 180 and $139{ }^{\circ} \mathrm{C}$ [47], respectively. By adopting the novel ultrasound-assisted SBA-16-nanocasting strategy, Deng et al. [48] and Xia et al. [50] have synthesized highly $3 \mathrm{D}$ ordered mesoporous $\mathrm{MnO}_{2}, \mathrm{Co}_{3} \mathrm{O}_{4}$, and $\mathrm{Cr}_{2} \mathrm{O}_{3}$ with high surface areas $\left(266,313\right.$, and $\left.124 \mathrm{~m}^{2} / \mathrm{g}\right)$. The dramatically enhanced surface area of these materials was attributed to that ultrasonic irradiation promoted liquid-solid mass transfer and dispersion of the metal precursors in the pores of the silica template. The catalytic activities of the porous TMOs materials were investigated for the combustion of a series of VOCs, such as toluene, formaldehyde, acetone, and methanol.

Recently, 3D ordered crystalline mesoporous $\mathrm{CeO}_{2}, \mathrm{Co}_{3} \mathrm{O}_{4}$, $\mathrm{Cr}_{2} \mathrm{O}_{3}, \mathrm{CuO}, \mathrm{Fe}_{2} \mathrm{O}_{3}, \mathrm{MnO}_{2}, \mathrm{Mn}_{2} \mathrm{O}_{3}, \mathrm{Mn}_{3} \mathrm{O}_{4}, \mathrm{NiO}$, and $\mathrm{NiCoMnO}_{4}$ were used for $\mathrm{CO}$ oxidation (Fig. 1) [68]. Among these, $\mathrm{Co}_{3} \mathrm{O}_{4}$, $\mathrm{MnO}_{2}$, and $\mathrm{NiO}$ showed appreciable $\mathrm{CO}$ conversions below $0{ }^{\circ} \mathrm{C}$. $\mathrm{Fe}_{2} \mathrm{O}_{3}$ was the least active. The catalytic activities of these materials were found to depend on the pretreatment temperature. By taking into account the lower metal-oxygen bond energy of $\mathrm{Co}_{3} \mathrm{O}_{4}, \mathrm{MnO}_{2}$, and $\mathrm{NiO}$, it was reasonably explained that the pretreatment in air at a moderate temperature was efficient for oxygen abstraction from the surface of these metal oxides to form surface oxygen vacancies, hence enhancing the adsorption and activation of $\mathrm{O}_{2}$ [69]. According to the literature, $\mathrm{MnO}_{2}$ and $\mathrm{Co}_{3} \mathrm{O}_{4}$ among the transition metal oxides are the most catalytically active for VOC and CO oxidation. A recent work found that the $3 \mathrm{D}$ mesoporous tetragonal $\mathrm{MnO}_{2}$ catalysts $\left(T_{90 \%}\right.$ corresponding to a VOC conversion of $90 \%$ was $217-220^{\circ} \mathrm{C}$ ) were superior to the 3D mesoporous cubic $\mathrm{Co}_{3} \mathrm{O}_{4}$ catalysts $\left(T_{90}=\right.$ $233-240{ }^{\circ} \mathrm{C}$ ) in catalyzing the oxidation of toluene. But the latter $\left(T_{90}=129-132{ }^{\circ} \mathrm{C}\right)$ outperformed the former $\left(T_{90}=\right.$ $158-178^{\circ} \mathrm{C}$ ) in catalyzing the oxidation of $\mathrm{CO}$ [70].

$\mathrm{Co}_{3} \mathrm{O}_{4}$ with a spinel structure is a very active catalyst for the oxidation of $\mathrm{CO}$. In these catalysts, octahedrally coordinated $\mathrm{Co}^{3+}$ is considered to be the active site, while tetrahedrally coordinated $\mathrm{Co}^{2+}$ is assumed to be inactive. Recently, a highly ordered mesoporous $\mathrm{CoO}$ was prepared by $\mathrm{H}_{2}$ reduction of nanocast $\mathrm{Co}_{3} \mathrm{O}_{4}$ at low temperatures by Jia and coworkers. The $\mathrm{CoO}$ material prepared has a rock salt structure with a single $\mathrm{Co}^{2+}$ octahedrally coordinated by lattice oxygen in Fm3m symmetry. It exhibited unusually high activity for CO oxidation. Careful investigation on the catalytic behavior of the mesoporous $\mathrm{CoO}$ catalyst led to the conclusion that the oxidation of surface $\mathrm{Co}^{2+}$ to $\mathrm{Co}^{3+}$ gave high activity [71]. Copper/ceria-based catalysts are considered the most promising candidates for the
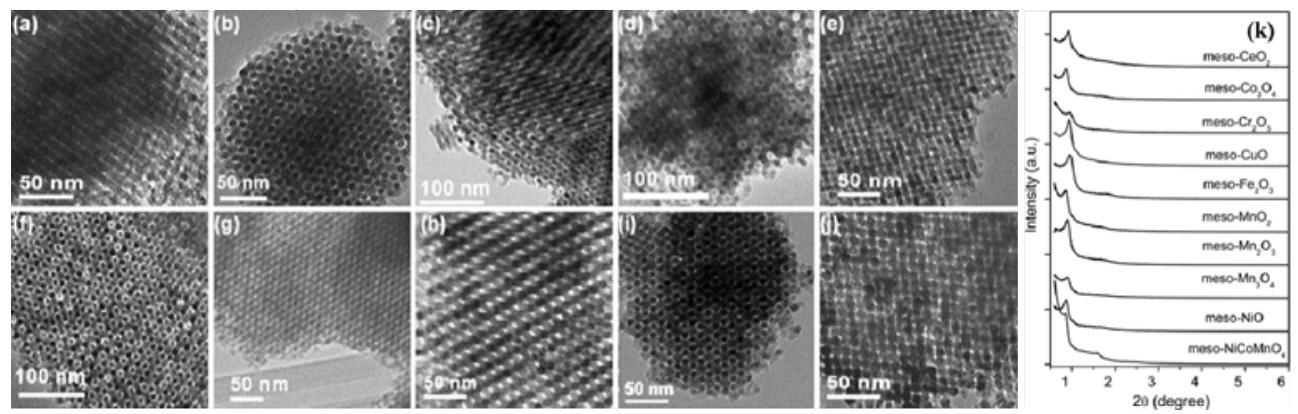

Fig. 1. TEM images (a-j) and low angle XRD patterns (k) of ordered crystalline mesoporous metal oxides. (a) $\mathrm{CeO}_{2}$; (b) $\mathrm{Co}_{3} \mathrm{O}_{4}$; (c) $\mathrm{Cr}_{2} \mathrm{O}_{3}$; (d) $\mathrm{CuO}$; (e) $\mathrm{Fe}_{2} \mathrm{O}_{3}$; (f) $\beta-\mathrm{MnO}_{2}$; (g) $\mathrm{Mn}_{2} \mathrm{O}_{3}$; (h) $\mathrm{Mn}_{3} \mathrm{O}_{4}$; (i) NiO; (j) NiCoMnO . Reproduced with permission from Ref. [68]. 
preferential oxidation of CO (PROX) process because of their low cost and high selectivity [72]. Kleitz and coworkers [73] investigated the catalytic performance of nanocast mesoporous $\mathrm{Cu} / \mathrm{CeO}_{2}$ and $\mathrm{CuM} / \mathrm{CeO}_{2}(\mathrm{M}=\mathrm{Fe}$ and $\mathrm{Co})$ mixed oxides for their effectiveness in the CO-PROX reaction. The catalytic performance of these materials among copper/ceria-based compositions was the best both with respect to $\mathrm{CO}$ conversion and $\mathrm{CO}_{2}$ selectivity at low temperatures. A complete $\mathrm{CO}$ conversion with $100 \%$ selectivity was achieved at $40{ }^{\circ} \mathrm{C}$ in the case of $\mathrm{Cu} / \mathrm{CeO}_{2}$ synthesized using KIT- 6 silica after aging at $40{ }^{\circ} \mathrm{C}$. The molar amount of $\mathrm{Cu}$ was $30 \%$. Interestingly, negligible decline was observed in the performance of these materials even after three cycles of operation. He et al. [74] synthesized 3D ordered mesoporous $\mathrm{CuO}_{x}-\mathrm{CeO}_{2}$ catalysts through the metal nitrate precursor host-guest interaction with SBA-16 silica as hard template. Their catalysts with 3D mesoporous structures have much higher low temperature activity for the complete oxidation of epichlorohydrin. The $T_{50}$ temperature of the $3 \mathrm{D}$-structured catalysts was decreased more than $130{ }^{\circ} \mathrm{C}$ as compared to the bulk $\mathrm{CeO}_{2}$ catalyst.

Another interesting class of mixed metal oxides are perovskites $\left(\mathrm{ABO}_{3}\right)$. In catalytic applications, these materials comprise a rare earth metal in the A site and a transition metal in the $\mathrm{B}$ site. In addition, these materials can be synthesized by partially substituting either or both the A and B sites. The efficiency of these perovskites, either substituted or not, is well documented for the catalytic oxidation of VOC [75]. However, a major challenge in the commercialization of these materials is their low specific surface areas resulting from the required high temperature calcination during the synthesis [72]. For this reason, one major objective regarding these materials is to produce them with enhanced surface areas. Although several solid and liquid phase synthesis methods were developed, the surface areas achieved still remained below $30 \mathrm{~m}^{2} / \mathrm{g}$. Wang et al. [76] performed a catalytic study on nanocast perovskites. The efficiency of mesoporous $\mathrm{LaCoO}_{3}$ was monitored for the total oxidation of methane and was compared with a bulk counterpart obtained from the citrate method. The light-off temperature (denoted as $T_{10}$ ) and half-conversion temperature $\left(T_{50}\right)$ were 335 and $470{ }^{\circ} \mathrm{C}$, respectively, and were much lower than those over the bulk perovskite at a space velocity of 60000 $\mathrm{h}^{-1}$. A series of perovskites were also synthesized using nanocasting method by Kleitz and coworkers [77]. Even though the resulting materials were not the exact replica of the template, extremely high surface areas (110-155 $\mathrm{m}^{2} / \mathrm{g}$ ) were obtained. The mesoporous $\mathrm{LaMnO}_{3}$ catalysts showed the highest conversion efficiency for methanol oxidation under steady state conditions as compared with both $\mathrm{LaCoO}_{3}$ and $\mathrm{LaFeO}_{3}$ nanocasts and $\mathrm{LaMnO}_{3}$ prepared by other methods. Gao et al. [78] prepared a porous wormhole-like $\mathrm{LaFeO}_{3}$ perovskite with a surface area of $138 \mathrm{~m}^{2} / \mathrm{g}$ using the hard templating method. The mesoporous $\mathrm{LaFeO}_{3}$ sample showed better catalytic performance: $T_{50}$ and $T_{90}$ were 155 and $180{ }^{\circ} \mathrm{C}$ for $\mathrm{CO}$ oxidation, and 200 and $253{ }^{\circ} \mathrm{C}$ for toluene oxidation at SV $=20000 \mathrm{~mL} /(\mathrm{g} \mathrm{h})$, respectively. Table 1 summarizes the catalytic activity of various mesoporous catalysts for VOC oxidation reported in the literature.

\subsection{Mesoporous transition metal oxide-supported noble metal catalysts}

Noble metal nanoparticles (NPs) finely dispersed on high surface area oxides are the most widely used heterogeneous catalysts. The catalytic activity and selectivity of the supported NPs strongly depend on their sizes and shapes and metal-support interactions [79]. One of the greatest challenges in the catalysis of supported NPs is the deactivation of catalysts under realistic conditions. Continuous operation at a high tem-

Table 1

Catalytic performance for VOC oxidation over ordered mesoporous transition metal oxide and supported noble metal catalysts.

\begin{tabular}{|c|c|c|c|c|c|c|c|}
\hline Catalyst & Noble metal loading (wt\%) & VOC volumetric concentration & VOC $/ \mathrm{O}_{2}$ molar ratio & SV & $T_{50}$ & $T_{90}$ & Ref. \\
\hline meso- $\mathrm{Cr}_{2} \mathrm{O}_{3}$ & - & $0.1 \%$ toluene & $1: 400$ & 20000 & 140 & 190 & [49] \\
\hline meso- $\mathrm{MnO}_{2}$ & - & $0.1 \%$ toluene & $1: 400$ & 20000 & 203 & 217 & {$[70]$} \\
\hline meso- $\mathrm{Co}_{3} \mathrm{O}_{4}$ & - & $0.1 \%$ toluene & $1: 20$ & 20000 & 140 & 180 & {$[47]$} \\
\hline meso- $\mathrm{MnO}_{2}$ & - & $0.1 \%$ toluene & $1: 200$ & 20000 & 190 & 240 & {$[48]$} \\
\hline meso- $\mathrm{Co}_{3} \mathrm{O}_{4}$ & - & $0.01 \%$ toluene & $1: 1000$ & 60000 & 163 & 195 & {$[66]$} \\
\hline meso- $\mathrm{Cr}_{2} \mathrm{O}_{3}$ & - & $0.05 \%$ formaldehyde & $1: 300$ & 30000 & 92 & 117 & {$[50]$} \\
\hline meso- $\mathrm{MnO}_{2}$ & - & $0.03 \%$ ethanol & $1: 350$ & 45000 & 70 & 130 & {$[64]$} \\
\hline meso- $\mathrm{CeO}_{2}$ & - & $0.045 \%$ naphthalene & $1: 450$ & 75000 & 235 & 275 & {$[65]$} \\
\hline meso- $\mathrm{CuO}_{x}-\mathrm{CeO}_{2}$ & - & $0.03 \%$ epichlorohydrin & $1: 700$ & 18400 & 143 & 174 & [74] \\
\hline meso-CoO & - & $1 \% \mathrm{CO}$ & $1: 20$ & 80000 & -36 & 50 & [71] \\
\hline meso- $\mathrm{Co}_{3} \mathrm{O}_{4}$ & - & $1 \% \mathrm{CO}$ & $1: 8$ & 44400 & -64 & -50 & {$[68]$} \\
\hline meso- $\gamma-\mathrm{MnO}_{2}$ & - & $0.2 \% \mathrm{CO}$ & $1: 50$ & 120000 & 89 & 100 & [107] \\
\hline meso- $\mathrm{LaFeO}_{3}$ & - & $0.1 \%$ toluene & $1: 400$ & 20000 & 200 & 253 & [78] \\
\hline meso- $\mathrm{LaFeO}_{3}$ & - & $0.15 \%$ chloromethane & $1: 65$ & 15000 & 425 & 500 & {$[62]$} \\
\hline meso-LaMnO 3 & - & $0.5 \%$ methanol & $1: 10$ & 39100 & 140 & 149 & [77] \\
\hline$m e s o-\mathrm{LaCoO}_{3}$ & - & $0.8 \%$ methane & $1: 6$ & 60000 & 470 & 600 & {$[76]$} \\
\hline $\mathrm{Au} / \mathrm{meso}-\mathrm{Co}_{3} \mathrm{O}_{4}$ & 6.5 & $0.1 \%$ benzene & $1: 400$ & 20000 & 162 & 189 & [88] \\
\hline $\mathrm{Au} /$ meso- $\beta-\mathrm{MnO}_{2}$ & 4.0 & $0.2 \%$ benzene & $1: 400$ & 60000 & 200 & 250 & [89] \\
\hline $\mathrm{Ag} / \mathrm{meso}^{-} \mathrm{Co}_{3} \mathrm{O}_{4}$ & 6.4 & $0.01 \%$ formaldehyde & $1: 2000$ & 30000 & 25 & 65 & [85] \\
\hline $\mathrm{Pd} / \mathrm{meso}^{-} \mathrm{Co}_{3} \mathrm{O}_{4}$ & 1.0 & $0.015 \% o$-xylene & 1:1400 & 60000 & 193 & 204 & [90] \\
\hline
\end{tabular}


perature generally leads to the sintering of NPs, resulting in a loss of surface metal atoms and substantial changes in the metal-support interface. Many strategies have been applied to reduce the sintering issue of noble metal NPs [80-82]. Suppressing atom migration is an effective way to control the problem of sintering, but it is more challenging relative to harnessing particle migration. When a non-reducible oxide (e.g., silica) is used as the support, it is very difficult to obtain an optimum particle size range of the noble metal particles due to the weak interaction between the noble metal and irreducible support. In these cases, an ordered mesoporous transition metal oxide with a well-defined pore size would be an appropriate support for the confinement of noble metal NPs. Moreover, the ordered pore system of the support is helpful in controlling the dispersion of the multicomponent active phase(s). In this aspect, the supports such as mesoporous $\mathrm{Co}_{3} \mathrm{O}_{4}, \mathrm{MnO}_{x}$, and $\mathrm{CeO}_{2}$ are especially valuable as their porous structure is periodic and their pore size can be controlled to be within a range of a few nanometers.

Low temperature catalysts of mesoporous $\mathrm{Co}_{3} \mathrm{O}_{4}$ and $\mathrm{Au} / \mathrm{Co}_{3} \mathrm{O}_{4}$ with high catalytic activities for the oxidation of trace ethylene at $0{ }^{\circ} \mathrm{C}$ were reported. The synthesized $\mathrm{Au} / \mathrm{Co}_{3} \mathrm{O}_{4}$ materials, in which the gold NPs were assembled into the pore walls of the mesoporous $\mathrm{Co}_{3} \mathrm{O}_{4}$ support possessed stable, highly dispersed, and exposed Au sites. Over the gold NPs present on $\mathrm{Co}_{3} \mathrm{O}_{4}$ with the reactive planes $\{110\}$, surface active oxygen species can be readily generated, thus promoting ethylene oxidation with a $76 \%$ conversion at $0{ }^{\circ} \mathrm{C}$, which was the highest conversion reported so far [83]. Formaldehyde (HCHO) is regarded as a major indoor pollutant emitted from widely used building and decorative materials in airtight buildings, which needs to be eliminated. Recently, $\mathrm{Ma}$ et al. [84] found that mesoporous $\mathrm{Co}_{3} \mathrm{O}_{4}$ generated from SBA-15 silica with predominately exposed $\{110\}$ facets and mainly $\mathrm{Co}^{3+}$ cations were the main active facets for HCHO oxidation. These adsorb and acti- vate $\mathrm{HCHO}$ species on the surface of $\mathrm{Co}_{3} \mathrm{O}_{4}$. The surface active oxygen species on the $\mathrm{Co}_{3} \mathrm{O}_{4}$-supported gold catalyst can be generated more readily, hence improving the oxidation of HCHO. HCHO can be oxidized into formate, and was further oxidized into carbonate that then dissociated to $\mathrm{CO}_{2}$. The proposed reaction mechanism was a pathway where only $\mathrm{C}-\mathrm{H}$ bonds were broken while the $\mathrm{C}-\mathrm{O} \sigma$ and $\mathrm{C}-\mathrm{O} \pi$ bonds were unchanged. Recently, Li's group reported that alkali metal ions could act as a promoter to improve the catalytic activity for $\mathrm{HCHO}$ oxidation on a mesoporous $\mathrm{Co}_{3} \mathrm{O}_{4}$-supported $\mathrm{Ag}$ catalyst. They discussed the effect of $\mathrm{K}^{+}$ions on catalytic performance. The turnover frequency (TOF) on $1.7 \mathrm{wt} \% \mathrm{~K}-\mathrm{Ag} / \mathrm{Co}_{3} \mathrm{O}_{4}$ was $0.22 \mathrm{~s}^{-1}$ at $60{ }^{\circ} \mathrm{C}$ and $\mathrm{HCHO}$ conversion was $55 \%$ at room temperature. They attributed the good catalytic performance to the surface $\mathrm{OH}^{-}$species provided by $\mathrm{K}^{+}$ions and the more abundant $\mathrm{Ag}$ (111) active face as well as $\mathrm{Co}^{3+}$ cations [85]. In order to investigate the oxide-metal interface effect on catalytic $\mathrm{CO}$ oxidation in both excess $\mathrm{O}_{2}$ and excess $\mathrm{CO}$, a serious of mesoporous oxides $\left(\mathrm{Co}_{3} \mathrm{O}_{4}, \mathrm{NiO}, \mathrm{MnO}_{2}, \mathrm{Fe}_{2} \mathrm{O}_{3}\right.$, and $\left.\mathrm{CeO}_{2}\right)$ were synthesized and loaded with size-controlled Pt NPs by Somorjai's group (Fig. 2). Through in situ characterization using near-edge X-ray absorption fine structure (NEXAFS) and ambient pressure X-ray photoelectron spectroscopy (APXPS) under alternating redox conditions combined with catalytic activity measurements, they found that the active surface phases of the oxide at the interface with $\mathrm{Pt} \mathrm{NPs}$ in the $\mathrm{CoO}-, \mathrm{Mn}_{3} \mathrm{O}_{4-}^{-}$, and $\mathrm{CeO}_{2}$-supported catalysts were responsible for the orders of magnitude enhancement in CO oxidation rate (Fig. 2) [86].

In recent years, supported Au catalysts have attracted tremendous attention, but Au NPs are easily sintered at relatively low temperatures. This results in the deactivation of the supported Au catalysts [87]. The dispersion of Au NPs on high surface area supports is expected to promote the catalytic activity and stability because it helps to not only increase the gold

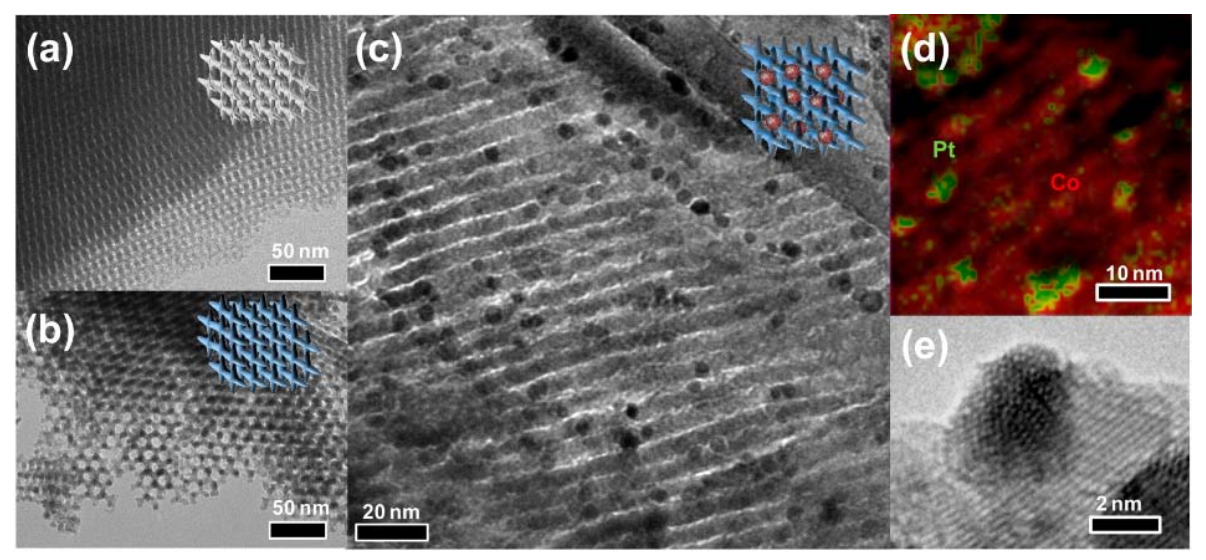

(f)
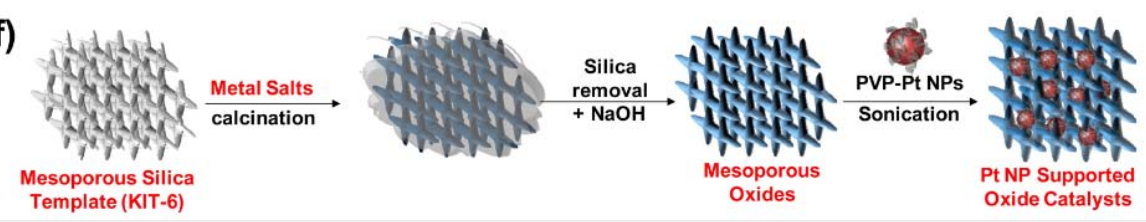

Fig. 2. Preparation of Pt NPs loaded on $\mathrm{Co}_{3} \mathrm{O}_{4}$. TEM images of mesoporous silica template (a) and resulting $\mathrm{Co}_{3} \mathrm{O}_{4}$ replica (b); (c) TEM image of $\mathrm{Pt} / \mathrm{Co}_{3} \mathrm{O}_{4}$ catalysts and (d) their energy dispersive spectroscopy (EDS) phase mapping (showing the merged image of the Co K (red) and Pt L (green) lines); (e) high resolution TEM image of $\mathrm{Pt} / \mathrm{Co}_{3} \mathrm{O}_{4}$ catalyst; and (f) illustration of the hard-templating (nanocasting) approach for the preparation of mesoporous oxide-supported Pt NP catalysts. Reproduced with permission from Ref. [86]. 
loading but also improve its dispersion and would be beneficial for preventing sintering of Au NPs [87]. Recently, Dai's and Ye's groups developed a novel method to synthesize ordered mesoporous $\mathrm{Co}_{3} \mathrm{O}_{4}$ - and $\beta$ - $\mathrm{MnO}_{2}$-supported $\mathrm{Au}$ catalysts. The $\mathrm{Au}$ NPs with a size of 2-5 nm were uniformly deposited inside the mesoporous channels of the metal oxide. There were good correlations of high adsorbed oxygen species concentration, high oxidized gold species concentration, and good low temperature reducibility as well as the high quality 3D ordered mesoporous structure with the catalytic activity of the sample for CO or BTX (benzene, toluene, and $o$-xylene) oxidation. The effects of water vapor, $\mathrm{CO}_{2}$, and $\mathrm{SO}_{2}$ on the catalytic performance of the samples were also examined [88,89]. After investigating ordered mesoporous $\mathrm{Co}_{3} \mathrm{O}_{4}$-supported $\mathrm{Pd}$ catalysts for $o$-xylene oxidation, Wang et al. $[90,91]$ pointed out that the good catalytic performance of $\mathrm{Pd} /$ porous $\mathrm{Co}_{3} \mathrm{O}_{4}$ was associated with the $\mathrm{Pd}$ particle size, oxidized $\mathrm{Pd}$ species, and oxygen vacancies in $\mathrm{Co}_{3} \mathrm{O}_{4}$. Moreover, catalytic oxidation of $\mathrm{CO}$ was investigated over a serious of Pd-deposited ordered mesoporous TMO catalysts. The authors claimed that the activity of a Pd-loaded catalyst was dependent on the type of support and metal-support interaction. They found that an in situ $\mathrm{H}_{2}$ pretreatment before the test resulted in a significant enhancement in catalytic activity at low temperatures. This indicated that the $\mathrm{H}_{2}$ pretreatment might be important for the metal-support interaction, formation of oxygen vacancies on the support, and generation of hydroxyl groups around Pd [92].

Previous attention was mostly paid to understanding the role of the active species in the catalytic oxidation of VOCs. However, it should be noted that the catalytic activity is also closely related to the interaction between the reactant and catalyst. VOC molecules are first adsorbed on the catalyst surface and then oxidized to $\mathrm{CO}_{2}$ and $\mathrm{H}_{2} \mathrm{O}$. Several research works have pointed out that the pore structure influence the adsorption behavior of VOCs on the catalyst surface. For example, Bai et al. [64] found that 3D mesoporous $\mathrm{MnO}_{2}$ had a special pore channel structure (which benefits the adsorption and diffusion of reactants and products) giving much better catalytic performance than the non-porous counterpart for ethanol oxidation. $\mathrm{He}$ and coworkers claimed that the Pd catalyst supported on a porous $\mathrm{SiO}_{2}$ with a bimodal micro- and mesoporous structure performed better than the Pd catalyst supported on a purely mesoporous $\mathrm{SiO}_{2}$ for toluene oxidation [93]. Based on the characterization results, the authors pointed out that the catalytic performance was associated with the toluene adsorption capability. That is, the higher toluene adsorption capability gave the higher catalytic activity. Overall, the easy diffusion of VOCs molecules inside the porous materials would benefit the improvement in catalytic activity.

\subsection{Ordered macroporous transition metal oxide catalysts}

Similarly, a range of macroscopic structures can also be formed through deliberate changes in the hard-templating synthesis of porous materials. Hard templates are often employed as a platform for producing hierarchically porous (e.g., three dimensionally ordered macroporous (3DOM)) materials
[38-45,94,95]. The synthesis of 3DOM materials involves the infiltration of a colloidal crystal template with a precursor, followed by calcination or pyrolysis to condense and, in many cases, crystallize the precursor(s) and remove the template used. Additional "soft" templating agents can also be added to the precursor, producing secondary pores in the walls of the material. Furthermore, morphological control is also desirable at larger length scales. This can be established with the sol-gel precursor and gelation processes.

Perovskites are known to be catalytically active for the complete oxidation of hydrocarbons and oxygenates. The catalytic activity of an $\mathrm{ABO}_{3}$ is associated with its surface area and pore structure. These factors are determined by the preparation method. The preservation of high surface area is important since the reaction rate is often proportional to the surface area of a bulk perovskite catalyst. The $\mathrm{ABO}_{3}$ materials derived from the hydrothermal [96], sol-gel [97], co-precipitation [98], and solid-state reaction [99] routes are usually nonporous and possess relatively low surface areas $\left(<10 \mathrm{~m}^{2} / \mathrm{g}\right)$, which are unfavorable for the facile accessibility of reactant molecules to active sites. Hence, it is highly desired to establish an effective method to controllably prepare $\mathrm{ABO}_{3}$ with a porous structure and high surface area. Dai and coworkers reported the synthesis of $\mathrm{LaMnO}_{3}$ using a hard-soft dual template approach where poly(methyl methacrylate) (PMMA) was used as the hard template. In order to develop mesopores in the walls of the macropores, a surfactant was added to the precursor. The soft template was observed to be beneficial for the generation of mesopores. In fact, using optimized contents of P123 and L-lysine, it is possible to generate an $\mathrm{ABO}_{3}$ material with a surface area of $39.4 \mathrm{~m}^{2} / \mathrm{g}$ and bimodal macro- and mesopores (Fig. $3)$. Under the conditions of toluene concentration $=1000 \mathrm{ppm}$, toluene $/ \mathrm{O}_{2}$ molar ratio $=1 / 400$, and $\mathrm{SV}=20000 \mathrm{~mL} /(\mathrm{g} \mathrm{h})$, the porous $\mathrm{LaMnO}_{3}$ catalysts were much superior to the bulk $\mathrm{LaMnO}_{3}$ catalyst in activity. Over the best performing catalyst, the $T_{50}$ and $T_{90}$ were 226 and $249{ }^{\circ} \mathrm{C}$, respectively. The kinetic studies revealed that the apparent activation energies (57 $\mathrm{kJ} / \mathrm{mol}$ ) for toluene combustion over the porous catalysts were much lower than that $(97 \mathrm{~kJ} / \mathrm{mol})$ over the bulk $\mathrm{LaMnO}_{3}$ catalyst (Fig. 3). They believed that the good catalytic performance of the 3DOM-structured $\mathrm{LaMnO}_{3}$ with mesoporous skeletons for toluene combustion was associated with the excellent textural properties (high surface area, unique bimodal pore structure) and physicochemical properties (high adsorbed oxygen species concentration and good low temperature reducibility) $[53,54]$. The thermal stability of the $3 \mathrm{DOM} \mathrm{ABO}_{3}$ was also examined. After being aged at $800{ }^{\circ} \mathrm{C}$ for methane combustion, the 3DOM architecture of $\mathrm{La}_{0.6} \mathrm{Sr}_{0.4} \mathrm{MnO}_{3}$ was still maintained. The used 3DOM sample exhibited a similar surface area to the fresh counterpart [100]. In the past several years, Dai's group has shown interest in developing strategies that generate a number of 3DOM-structured materials (e.g., $\mathrm{Fe}_{2} \mathrm{O}_{3}$ [101], $\mathrm{Pr}_{6} \mathrm{O}_{11}$ [102], $\mathrm{Tb}_{4} \mathrm{O}_{7}$ [102], $\mathrm{La}_{2} \mathrm{CuO}_{4}$ [103], $\mathrm{La}_{0.6} \mathrm{Sr}_{0.4} \mathrm{FeO}_{3-\delta}$ [104], $\mathrm{SrFeO}_{3-\delta}$ [105], and $\mathrm{La}_{0.6} \mathrm{Sr}_{0.4} \mathrm{Fe}_{0.8} \mathrm{Bi}_{0.2} \mathrm{O}_{3-\delta}$ [106]) with high surface areas by the surfactant-assisted PMMA-templating approaches. They observed that some of the 3DOM materials performed excellently in the oxidation of CO and typical VOCs. 

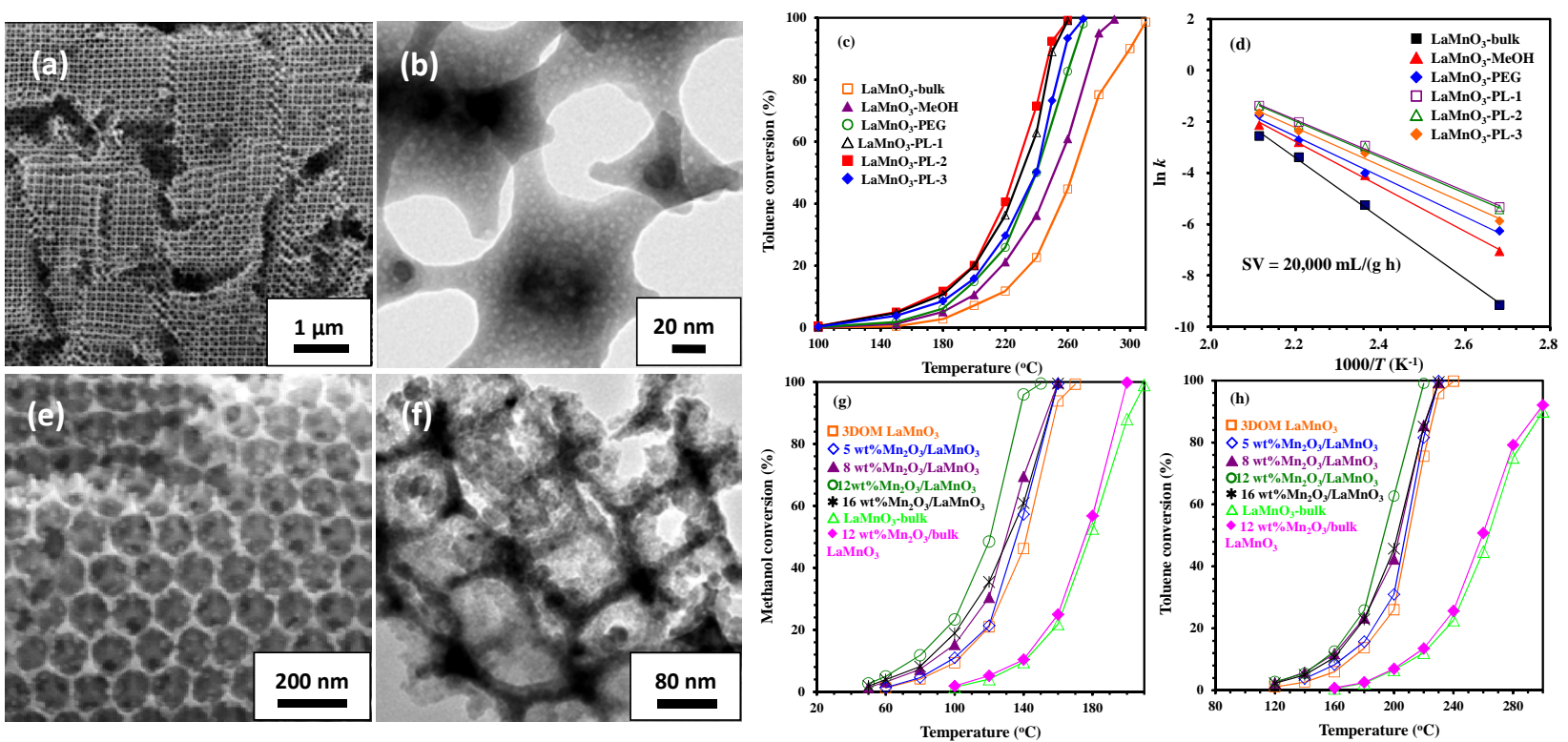

Fig. 3. SEM (a) and TEM (b) images of 3DOM $\mathrm{LaMnO}_{3}$ catalyst; (c) toluene conversion as a function of reaction temperature over LaMnO $\mathrm{C}_{3}$ catalysts; (d) Arrhenius plots for the oxidation of toluene over the $\mathrm{LaMnO}_{3}$ catalysts; SEM (e) and TEM (f) images of the $12 \mathrm{wt} \% \mathrm{MnO}_{x} / 3 \mathrm{DOM} \mathrm{LaMnO}_{3}$ catalyst; Methanol conversion (g) and toluene conversion (h) as a function of reaction temperature over the $\mathrm{MnO}_{x}$-loaded $\mathrm{LaMnO}_{3}$ catalysts under the conditions of VOC concentration $=1000 \mathrm{ppm}, \mathrm{VOC} / \mathrm{O}_{2}$ molar ratio $=1 / 400$, and SV $=20000 \mathrm{~mL} /(\mathrm{g} \mathrm{h})$. Reproduced with permission from Refs. [54,112].

Recently, Li's group found that 3DOM $\mathrm{LaMnO}_{3}$ can be treated with diluted $\mathrm{HNO}_{3}$ to selectively remove La cations, and obtained a novel porous $\gamma$ - $\mathrm{MnO}_{2}$-like material. Upon the removal of La cations, the sample showed a significantly higher CO oxidation catalytic activity $\left(T_{50}=89^{\circ} \mathrm{C}\right)$ than the initial precursor $\mathrm{LaMnO}_{3}\left(T_{50}=237^{\circ} \mathrm{C}\right)$ and conventional $\gamma-\mathrm{MnO}_{2}\left(T_{50}=148{ }^{\circ} \mathrm{C}\right)$. This finding not only suggested a new method to improve the catalytic activity, but also supplied a strategy to synthesize novel $\gamma$ - $\mathrm{MnO}_{2}$-like materials, which have potential applications in other fields [107].

In order to further increase the catalytic performance of $\mathrm{ABO}_{3}$, one solution is to load transition metal oxide(s) on the surface of $\mathrm{ABO}_{3}$. For supported transition metal oxide catalysts, a particular interest is the strong metal-support interaction (SMSI). There is a synergetic effect between the metal oxide and the support, which can strongly influence the electronic structure of the metal oxide. A number of attempts have been made to identify the synergistic interaction between the metal oxide and support, which has frequently been proposed to explain the high catalytic activities of $\mathrm{Co}_{3} \mathrm{O}_{4} / \mathrm{ZrO}_{2}$ [108], $\mathrm{Co}_{3} \mathrm{O}_{4}-\mathrm{MnO}_{x} / \mathrm{Ce}_{0.85} \mathrm{Zr}_{0.15} \mathrm{O}_{2}$ [109], and $\mathrm{CuO} / \mathrm{Ce}_{1-x} \mathrm{Cu}_{x} \mathrm{O}_{2-\delta}$ [110] for the oxidation of $\mathrm{CO}$ and VOCs. Ji et al. [111] synthesized 3DOM-structured $\mathrm{Eu}_{0.6} \mathrm{Sr}_{0.4} \mathrm{FeO}_{3}$ (ESFO) and $\mathrm{CoO}_{x} / 3 \mathrm{DOM}$ ESFO using citrate acid-assisted PMMA-templating and incipient wetness impregnation methods, respectively. All the supported samples retained a high quality 3DOM architecture with a surface area of $22-31 \mathrm{~m}^{2} / \mathrm{g}$. The cobalt oxide NPs with a diameter of 7-9 $\mathrm{nm}$ were highly dispersed on the surface of 3DOM ESFO. The apparent activation energy $(72 \mathrm{~kJ} / \mathrm{mol})$ of the $3 \mathrm{wt} \%$ $\mathrm{CoO}_{x} / 3$ DOM ESFO sample was much lower than that (81 $\mathrm{kJ} / \mathrm{mol}$ ) of the 3DOM ESFO support. The size and dispersion of a metal oxide on support are crucial factors influencing its cat- alytic performance. According to the literature, however, most of the supported metal oxide $\left(\mathrm{MO}_{\mathrm{x}}\right)$ catalysts display big particles of $\mathrm{MO}_{x}$ and poor $\mathrm{MO}_{x}$ dispersion. Furthermore, the supported $\mathrm{MO}_{x}$ catalysts are usually prepared using the incipient wetness impregnation method, causing difficulty in controlling the morphology of the metal oxide. Therefore, it is highly desired to develop a facile and one-step approach for the preparation of supported $\mathrm{MO}_{x}$ catalysts. Recently, Liu et al. [112] developed a novel in situ tryptophan-assisted PMMA-templating strategy to prepare $\mathrm{MnO}_{x} / 3 \mathrm{DOM} \mathrm{LaMnO}_{3}$ materials. By adding an excess amount of manganese precursor and with L-tryptophan as chelating agent, the $\mathrm{MnO}_{x} / 3 \mathrm{DOM}$ $\mathrm{LaMnO}_{3}$ samples were directly synthesized. The $12 \mathrm{wt} \%$ $\mathrm{MnO}_{x} / 3 \mathrm{DOM} \mathrm{LaMnO} \mathrm{O}_{3}$ sample contained $\mathrm{MnO}_{x} \mathrm{NPs}$ (4-18 nm in size) highly dispersed on the surface of 3DOM LaMnO 3 (Fig. 3). Under the conditions of toluene or methanol concentration = $1000 \mathrm{ppm}$, toluene or methanol $/ \mathrm{O}_{2}$ molar ratio $=1 / 400$, and SV $=20000 \mathrm{~mL} /(\mathrm{g} \mathrm{h})$, the $12 \mathrm{wt} \% \mathrm{MnO}_{x} / 3 \mathrm{DOM} \mathrm{LaMnO} 3$ sample exhibited the highest TOF of $7.9 \times 10^{-6} \mathrm{~s}^{-1}$ for toluene combustion at $160^{\circ} \mathrm{C}$ and $7.3 \times 10^{-6} \mathrm{~s}^{-1}$ for methanol combustion at 80 ${ }^{\circ} \mathrm{C}$ (Fig. 3). Table 2 gives an overview of the catalytic performance of various macroporous catalysts for VOC oxidation reported in the literature.

\subsection{Macroporous transition metal oxide-supported noble metal catalysts}

Generally, the strong metal-support interaction plays an important role in influencing the performance of supported catalysts. Many studies have assigned the origin of the catalytic activity of supported noble metal catalysts to the perimeter interfaces between the noble metal nanocrystals (NCs) and 
Table 2

Catalytic performance for VOC oxidation over ordered macroporous transition metal oxide and supported noble metal catalysts.

\begin{tabular}{|c|c|c|c|c|c|c|c|}
\hline Sample & Noble metal loading (wt\%) & VOC volumetric concentration & $\mathrm{VOC} / \mathrm{O}_{2}$ molar ratio & $\mathrm{SV}(\mathrm{mL} /(\mathrm{g} \mathrm{h}))$ & $T_{50}\left({ }^{\circ} \mathrm{C}\right)$ & $T_{90}\left({ }^{\circ} \mathrm{C}\right)$ & Ref. \\
\hline $3 \mathrm{DOM} \mathrm{Fe} \mathrm{O}_{3}$ & - & $0.1 \%$ toluene & $1: 400$ & 20000 & 240 & 290 & {$[101]$} \\
\hline 3DOM $\mathrm{LaMnO}_{3}$ & - & $0.1 \%$ toluene & $1: 400$ & 20000 & 222 & 243 & [53] \\
\hline 3DOM La0.6 $\mathrm{Sr}_{0.4} \mathrm{Fe}_{0.8} \mathrm{Bi}_{0.2} \mathrm{O}_{3-\delta}$ & - & $0.1 \%$ toluene & $1: 400$ & 20000 & 220 & 242 & [106] \\
\hline $3 \mathrm{DOM} \mathrm{Eu}_{0.6} \mathrm{Sr}_{0.4} \mathrm{FeO}_{3}$ & - & $0.1 \%$ toluene & $1: 400$ & 20000 & 250 & 270 & [111] \\
\hline $3 \mathrm{DOM} \mathrm{La}_{0.6} \mathrm{Sr}_{0.4} \mathrm{FeO}_{3-\delta}$ & - & $0.1 \%$ toluene & $1: 400$ & 20000 & 225 & 280 & [104] \\
\hline $3 \mathrm{DOM} \mathrm{SrFeO}_{3-\delta}$ & - & $0.1 \%$ toluene & $1: 400$ & 20000 & 292 & 340 & [105] \\
\hline 3DOM La ${ }_{0.6} \mathrm{Sr}_{0.4} \mathrm{MnO}_{3}$ & - & $2 \%$ methane & $1: 10$ & 30000 & 566 & 661 & [100] \\
\hline $3 \mathrm{DOM} \mathrm{La}_{2} \mathrm{CuO}_{4}$ & - & $2 \%$ methane & $1: 10$ & 50000 & 560 & 672 & [103] \\
\hline $\mathrm{MnO}_{x} / 3 \mathrm{DOM} \mathrm{LaMnO}_{3}$ & - & $0.1 \%$ toluene & $1: 400$ & 20000 & 193 & 215 & [112] \\
\hline $\mathrm{Ag} / 3 \mathrm{DOM} \mathrm{La}_{0.6} \mathrm{Sr}_{0.4} \mathrm{MnO}_{3}$ & 3.6 & $2 \%$ methane & $1: 10$ & 30000 & 454 & 524 & [122] \\
\hline $\mathrm{Pt} / 3 \mathrm{DOM} \mathrm{Ce}_{0.6} \mathrm{Zr}_{0.3} \mathrm{Y}_{0.1} \mathrm{O}_{2}$ & 1.1 & $2 \%$ methane & $1: 10$ & 30000 & 434 & 598 & [118] \\
\hline $\mathrm{Au} / 3 \mathrm{DOM} \mathrm{Co}_{3} \mathrm{O}_{4}$ & 6.5 & $0.1 \%$ toluene & $1: 400$ & 40000 & 244 & 256 & [120] \\
\hline $\mathrm{Au} / 3 \mathrm{DOM} \mathrm{Mn} \mathrm{O}_{3}$ & 5.8 & $0.1 \%$ toluene & $1: 400$ & 40000 & 230 & 244 & [124] \\
\hline $\mathrm{Au} / 3 \mathrm{DOM} \mathrm{LaCoO}_{3}$ & 7.6 & $0.1 \%$ toluene & $1: 400$ & 20000 & 188 & 202 & [121] \\
\hline $\mathrm{Au} / 3 \mathrm{DOM} \mathrm{La}_{0.6} \mathrm{Sr}_{0.4} \mathrm{MnO}_{3}$ & 6.4 & $0.1 \%$ toluene & $1: 400$ & 20000 & 150 & 170 & [117] \\
\hline $\mathrm{Au} / 3 \mathrm{DOM} \mathrm{LaMnO}_{3}$ & 4.9 & $0.1 \%$ toluene & $1: 400$ & 20000 & 201 & 226 & {$[55]$} \\
\hline $\mathrm{Au} / \mathrm{MnO}_{x} / 3 \mathrm{DOM} \mathrm{La}_{0.6} \mathrm{Sr}_{0.4} \mathrm{MnO}_{3}$ & 5.9 & $0.1 \%$ toluene & $1: 400$ & 20000 & 205 & 220 & [123] \\
\hline $\mathrm{Au}-\mathrm{Pd} / 3 \mathrm{DOM} \mathrm{Co}_{3} \mathrm{O}_{4}$ & 1.99 & $0.1 \%$ toluene & $1: 400$ & 40000 & 164 & 168 & [126] \\
\hline $\mathrm{Au} / 3 \mathrm{DOM} \mathrm{CeO}_{2}$ & 0.56 & $0.06 \%$ HCHO & $1: 350$ & 66000 & 28 & 50 & [115] \\
\hline
\end{tabular}

oxide support [113,114]. Charge transfer may also occur across the nanoscale interface, either from the noble metal to the oxide (e.g., $\mathrm{Au}-\mathrm{TiO}_{2}$ [113]) or from the oxide to the noble metal (e.g., $\mathrm{Fe}_{3} \mathrm{O}_{4}$ - $\mathrm{Pt}$ [114]) to promote the catalysis process.

Zhang and coworkers [115] found that their $\mathrm{Au} / 3 \mathrm{DOM} \mathrm{CeO}_{2}$ catalysts showed a unique 3DOM structure with interconnected networks of spherical voids favoring less aggregation and good distribution of small Au NPs, which gave enhanced catalytic activity for formaldehyde oxidation, with 100\% formaldehyde conversion achieved at a temperature as low as $75^{\circ} \mathrm{C}$. This was approximately $25{ }^{\circ} \mathrm{C}$ lower than with the previously reported $\mathrm{Au} /$ nonporous $\mathrm{CeO}_{2}$ catalysts. The characterization results of hydrogen temperature programmed reduction ( $\mathrm{H}_{2}$-TPR), formaldehyde temperature programmed surface reaction (HCHO-TPSR), $\mathrm{CO}_{2}$ temperature programmed desorption ( $\mathrm{CO}_{2}$-TPD), and Fourier transform infrared (FT-IR) spectroscopy reveal that the weak adsorption ability of $\mathrm{CO}_{2}$ on the $\mathrm{Au} / 3 \mathrm{DOM} \mathrm{CeO}_{2}$ catalyst and the co-existence of $\mathrm{Au}$ active species $\left(\mathrm{Au}^{3+}\right.$ and $\left.\mathrm{Au}^{0}\right)$ would account for the efficient catalytic oxidation of HCHO. The formation of carbonate and hydrocarbonate on the surface of $\mathrm{Au} / 3 \mathrm{DOM} \mathrm{CeO}_{2}$ derived from the incomplete oxidation of formate during the HCHO oxidation processes lead to the deactivation of catalytic activity. The carbonate and hydrocarbonate formed, however, would find it hard to block the active sites of the $\mathrm{Au} / 3 \mathrm{DOM} \mathrm{CeO}_{2}$ catalyst due to its large and open macroporous structure. Therefore, the $\mathrm{Au} / 3 \mathrm{DOM} \mathrm{CeO}_{2}$ catalyst showed good catalytic activity and stability for HCHO oxidation [116]. Liu et al. [55,117] reported the successful preparation of a chain-like ordered macroporous $\mathrm{LaMnO}_{3}$ and 3DOM La0.6Sro.4 $\mathrm{MnO}_{3}$ using the poly(ethylene glycol) (PEG)-assisted PMMA-templating method. Taking the chain-like $\mathrm{LaMnO}_{3}$ synthesis as an example, high quality colloidal crystals were infiltrated with a precursor solution containing PEG. Through controlled calcination and after removal of the polymer microspheres, one can obtain an initial 3DOM structure which was then disassembled into individual chain-like entities. Subsequent incipient wetness impregnation of the chain-like $\mathrm{LaMnO}_{3}$ support with a gold sol derived from the reduction of $\mathrm{HAuCl}_{4}$ by sodium borohydride using polyvinyl alcohol (PVA) as protecting agent was adopted to fabricate the chain-like $\mathrm{LaMnO}_{3}$-supported $\mathrm{Au}$ nanocatalysts. The catalytic oxidation of $\mathrm{CO}$ and toluene over these catalysts proceeded via a suprafacial mechanism. After loading gold, partial surface $\mathrm{Mn}^{4+}$ species were reduced to $\mathrm{Mn}^{3+}$ species by $\mathrm{Au}^{0}$ by the SMSI between $\mathrm{Au}$ NPs and $\mathrm{LaMnO}_{3}$, resulting in the formation of surface oxygen vacancies. Gas phase $\mathrm{O}_{2}$ molecules were activated on the oxygen vacancies near the $\mathrm{Au}-\mathrm{LaMnO}_{3}$ interface to active oxygen species. On the other hand, loading of Au NPs significantly promoted the adsorption of $\mathrm{CO}$ and toluene, thus enhancing the migration of chemisorbed $\mathrm{CO}$ and toluene to the $\mathrm{Au}-\mathrm{LaMnO}_{3}$ interface. The oxidation of $\mathrm{CO}$ and toluene occur between chemisorbed $\mathrm{CO}$ or toluene and active oxygen species at the $\mathrm{Au}-\mathrm{LaMnO}_{3}$ interface. A similar conclusion was drawn by Arandiyan et al. [118,119], who found that after Pt loading, the rise in $\mathrm{Ce}^{3+}$ content of the $\mathrm{Pt} / 3 \mathrm{DOM} \mathrm{Ce}_{0.6} \mathrm{Zr}_{0.3} \mathrm{Y}_{0.1} \mathrm{O}_{2}$ (CZY) samples indicated that a strong interaction existed between Pt and 3DOM CZY. This was due to the electron transfer from $\mathrm{Pt}^{0}$ to $\mathrm{Ce}^{4+}$ in the 3DOM CZY support (Fig. 4). In other words, the Pt atoms $\left(\mathrm{Pt}^{0} \rightarrow \mathrm{Pt}^{\delta+}\right)$ was oxidized by the surface Ce atoms $\left(\mathrm{Ce}^{4+}\right.$ $\rightarrow \mathrm{Ce}^{3+}$ ), even though there was no direct Pt-Ce bonding. After that, a series of macroporous transition metal oxide- or perovskite-type oxide-supported catalysts were prepared, such as $\mathrm{Au} / 3 \mathrm{DOM} \mathrm{Co}_{3} \mathrm{O}_{4}$ [120], $\mathrm{Au} / 3 \mathrm{DOM} \mathrm{LaCoO}_{3}$ [121], Ag/3DOM $\mathrm{La}_{0.6} \mathrm{Sr}_{0.4} \mathrm{MnO}_{3}$ [122], $\mathrm{Au} / \mathrm{MnO}_{x} / 3 \mathrm{DOM} \mathrm{La}_{0.6} \mathrm{Sr}_{0.4} \mathrm{MnO}_{3}$ [123], and $\mathrm{Au} / 3 \mathrm{DOM} \mathrm{Mn}_{2} \mathrm{O}_{3}$ [124].

In recent years, nanoalloys have been of interest due to their potential technological applications in catalysis $[125,126]$. From a basic science perspective, nanoalloys exhibit very com- 
plex structures and unique properties, which strongly depend not only on the particle size but also on the composition and atomic ordering. Recently, Xie et al. [126,127] synthesized $\mathrm{Au}-\mathrm{Pd} / 3 \mathrm{DOM} \mathrm{Co}_{3} \mathrm{O}_{4}(\mathrm{Au} / \mathrm{Pd}$ mass ratio $=1: 1)$ catalysts with a $\mathrm{Au}-\mathrm{Pd}$ NPs average size of 2.6-2.7 $\mathrm{nm}$. They showed that they were highly efficient for toluene oxidation. Characterization results revealed that the $\mathrm{Au}-\mathrm{Pd} / 3 \mathrm{DOM} \mathrm{Co}_{3} \mathrm{O}_{4}$ catalysts possessed stronger ability in activating oxygen and toluene and strong interaction between $\mathrm{Au}-\mathrm{Pd} \mathrm{NPs}$ and 3DOM $\mathrm{Co}_{3} \mathrm{O}_{4}$. The $\mathrm{Au}-\mathrm{Pd} / 3 \mathrm{DOM} \mathrm{Co}_{3} \mathrm{O}_{4}$ samples outperformed the 3DOM $\mathrm{Co}_{3} \mathrm{O}_{4}$-supported $\mathrm{Au}$ or $\mathrm{Pd}$ sample for toluene oxidation, with the $1.99 \mathrm{wt} \% \mathrm{Au}-\mathrm{Pd} / 3 \mathrm{DOM} \mathrm{Co}_{3} \mathrm{O}_{4}$ sample showing the highest catalytic activity (the $T_{10}, T_{50}$, and $T_{90}$ were 145,164 , and $168^{\circ} \mathrm{C}$ at $\mathrm{SV}=40000 \mathrm{~mL} /(\mathrm{g} \mathrm{h})$, respectively) (Fig. 5). Furthermore, the authors found that moisture introduction had a positive effect on the catalytic activity of the supported Au-Pd nanocatalyst for toluene oxidation. The supported noble metal alloy catalyst exhibited excellent catalytic and hydrothermal stability (Fig. 5).

Zhang and coworkers [128] demonstrated that the catalytic performance of $\mathrm{Pt}-\mathrm{Au} / 3 \mathrm{DOM} \mathrm{CeO} 2$ catalysts was much better than that of the $\mathrm{Pt} / 3 \mathrm{DOM} \mathrm{CeO}_{2}$ or $\mathrm{Au} / 3 \mathrm{DOM} \mathrm{CeO}_{2}$ catalyst. For the CO-PROX reaction, the Pt-Au/3DOM $\mathrm{CeO}_{2}$ catalyst showed superior catalytic performance with $90 \%$ CO conversion and $83 \% \mathrm{CO}_{2}$ selectivity at $80{ }^{\circ} \mathrm{C}$. The long term stability lifetime of
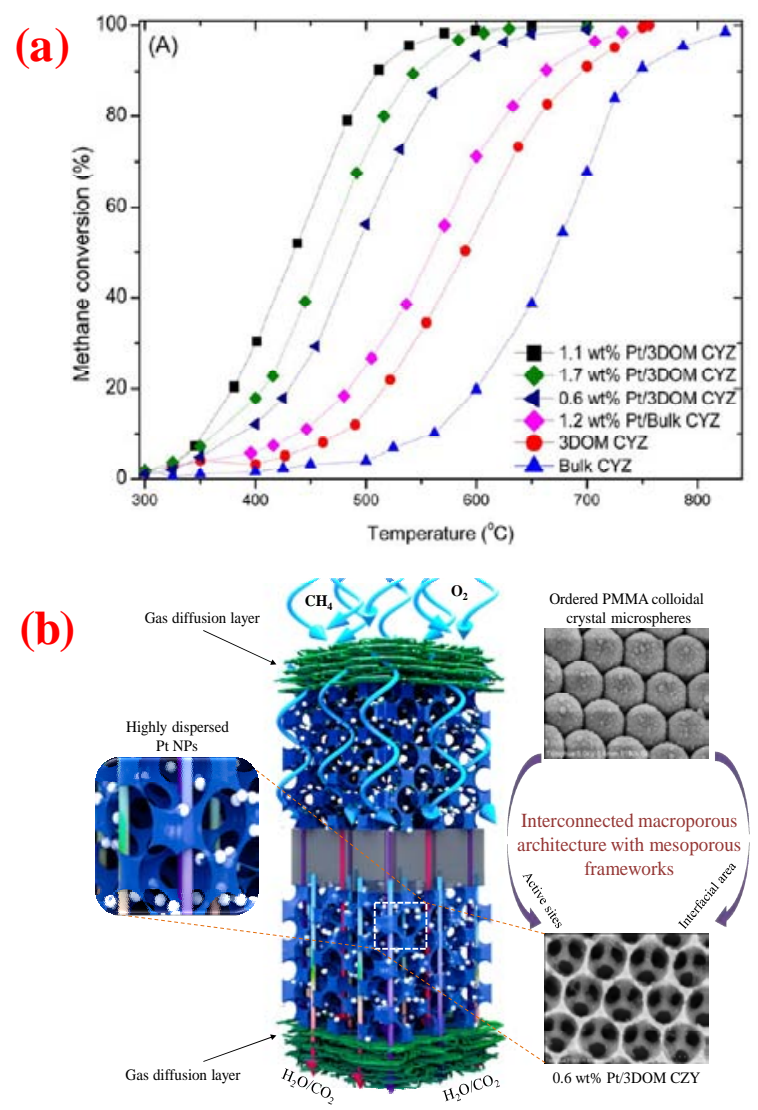

Fig. 4. (a) Methane conversion versus temperature over 3DOM $\mathrm{Ce}_{0.6} \mathrm{Zr}_{0.3} \mathrm{Y}_{0.1} \mathrm{O}_{2}$ (CZY), $x$ wt\% Pt/3DOM CZY, and bulk CZY catalysts under the conditions of $2 \% \mathrm{CH}_{4}+20 \% \mathrm{O}_{2}+78 \% \mathrm{~N}_{2}$ (balance) and GHSV = $30000 \mathrm{~mL} /(\mathrm{g} \mathrm{h})$; (b) schematic illustration of loading Pt NPs on 3DOM CZY catalysts. Reproduced with permission from Ref. [118]. the alloyed catalyst can be realized with $90 \%$ CO conversion and $56 \% \mathrm{CO}_{2}$ selectivity even after $260 \mathrm{~h}$ of running time.

\section{Conclusive remarks and prospect}

Catalytic oxidation is the most important method for the removal of VOCs, especially low concentration organics. Transition metal oxides, such as $\mathrm{MnO}_{x}, \mathrm{Co}_{3} \mathrm{O}_{4}$, and $\mathrm{CuO}$, are better than the supported noble metal catalysts because of their comparable catalytic performance for the deep oxidation of VOCs and their much lower cost. Transition metal oxides are considered as "active" supports for supported noble metal catalysts, by both allowing the reduction of the noble metal loaded and increasing their life time. However, transition metal oxides suffer from several disadvantages, such as low thermal stability and high sensitivity to poisoning. As an alternative, perovskites have received wide attention and often showed good catalytic performance. The catalytic properties of $\mathrm{ABO}_{3}$ and $\mathrm{A}_{2} \mathrm{BO}_{4}$ materials are easily tuned by partial substitution in the lattice. But the preparation of single phase perovskites is usually conducted at high temperatures and long calcination times, inevitably leading to rather low surface areas but high thermal stability. The solutions proposed to overcome these drawbacks of perovskites were by calcining the materials in a reducing atmosphere.

This review provided a complete survey from a perspective on the development of ordered porous transition metal oxide and supported noble metal catalysts for VOC oxidation. Examples of ordered meso- and macroporous transition metal oxide and supported noble metal catalysts were highlighted. Porous catalysts showed much better catalytic performance than their bulk and even nanosized counterparts. The excellent catalytic performance of porous materials is associated with their high surface areas, high adsorbed oxygen species concentrations, good low temperature reducibility, strong interaction between the noble metal and support and highly dispersed noble metal NPs and unique porous structures. In addition, the catalytic performance for VOC oxidation was also influenced by experimental parameters, such as space velocity and concentration of initial VOCs, water vapor, carbon dioxide, and sulfur dioxide. Based on the understanding of the reaction mechanisms at the molecular level, the ultimate goal of this review is to help rational design and successfully synthesize efficient catalysts with defined active sites.

There are still several critical issues to be addressed with these materials in environmental catalysis. First, the hard-templating method was used extensively to synthesize ordered porous metal oxides, but it is not a direct one-step method and the preparation is too expensive to be scaled up. Therefore, more efforts should be devoted to the development of alternative convenient synthesis strategies. For example, by using cheap natural minerals as the hard template instead of artificially synthesized silica and polymers, the nanocasting method is versatile for the fabrication of a variety of nanoporous metal oxides that have pores on multiple scales. Another improvement is to use the hydrothermal method with cheap surfactants to synthesize nanoporous metal oxides with dual 
(a)

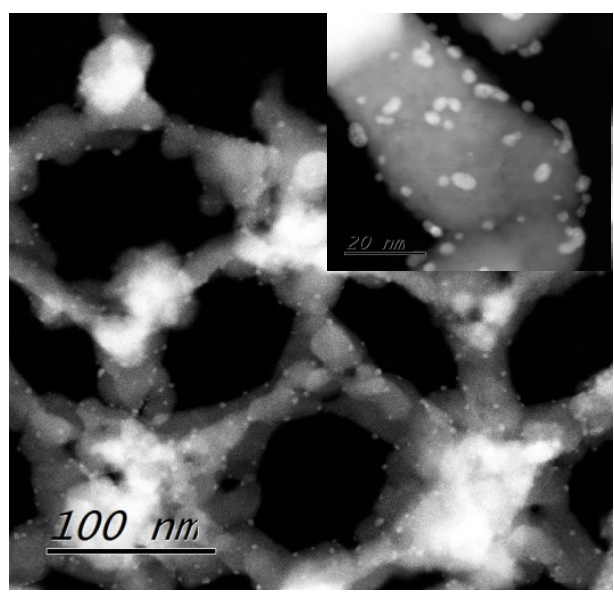

(c)

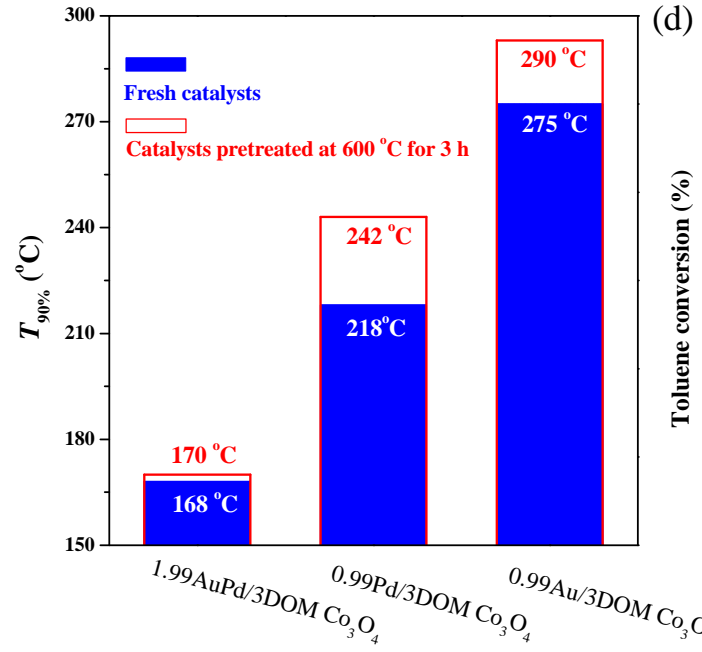

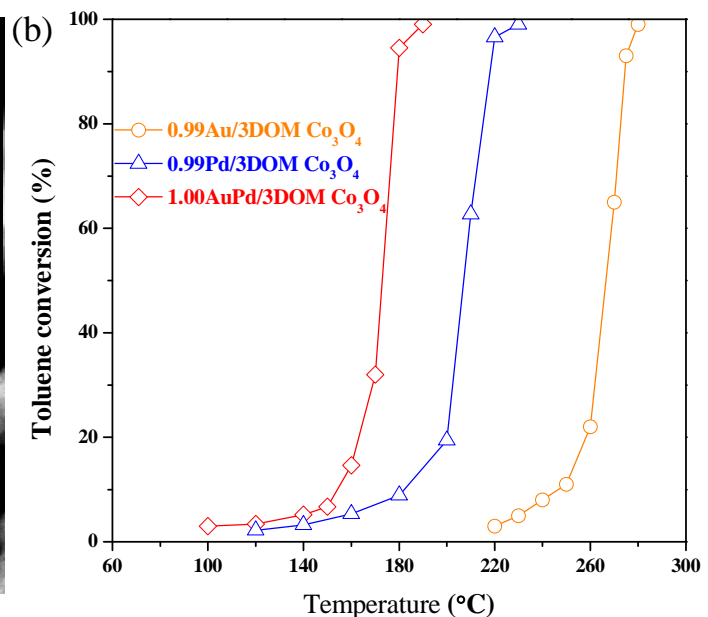

(d)

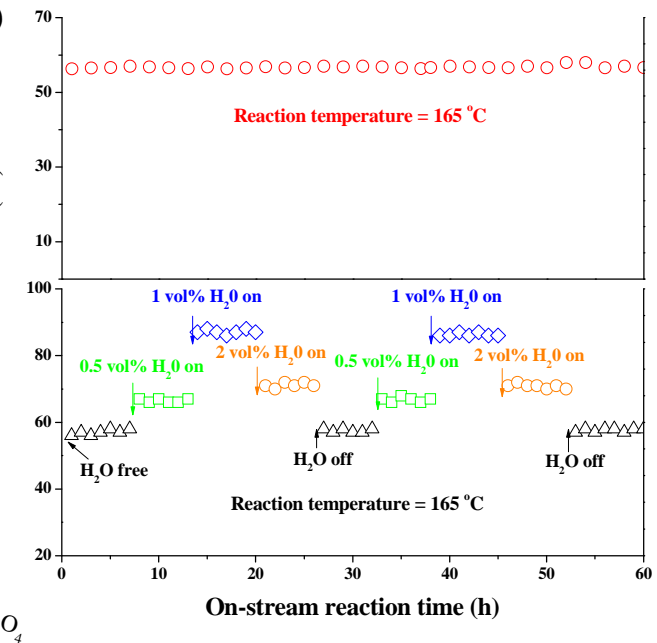

Fig. 5. (a) HAADF-STEM image of Au-Pd/3DOM $\mathrm{Co}_{3} \mathrm{O}_{4}$; (b) toluene conversion as a function of reaction temperature over $\mathrm{Au}-\mathrm{Pd} / 3 \mathrm{DOM} \mathrm{Co}_{3} \mathrm{O}_{4}$ samples at $\mathrm{SV}=40000 \mathrm{~mL} /(\mathrm{g} \mathrm{h})$; (c) $T_{90}$ values for toluene oxidation over the catalysts before and after pretreatment in nitrogen at $600{ }^{\circ} \mathrm{C}$ for $3 \mathrm{~h}$; (d) on-stream toluene oxidation at $165^{\circ} \mathrm{C}$ and effect of water vapor addition on catalytic activity at $165{ }^{\circ} \mathrm{C}$ over $1.99 \mathrm{wt} \% \mathrm{Au}-\mathrm{Pd} / 3 \mathrm{DOM} \mathrm{Co} \mathrm{O}_{4}$ at $\mathrm{SV}=$ $40000 \mathrm{~mL} /(\mathrm{g} \mathrm{h})$. Reproduced with permission from Ref. [126].

micro- and mesoporosity. The challenge is the generation of porous metal oxides with crystalline walls in the absence of a hard template. Second, the removal of mixed VOCs in humid air at low temperature is a great challenge in practical industrial applications. Hybrid processes that combine different technologies are an interesting direction for future study since each of the methods for VOC elimination has its own advantages and limitations. The coupling of multiple remediation technologies, such as adsorption-catalysis combination, photocatalysis-thermocatalysis combination, and plasma-catalysis combination can be good choices for the effective removal of VOCs.

\section{References}

[1] R. M. Heck, R. J. Farrauto, Catalytic Pollution Control, 2nd ed., Wiley Interscience, New York, 2002.

[2] A. G. Carlton, C. Wiedinmyer, J. H. Kroll, Atmos. Chem. Phys, 2009, 9, 4987-5005.

[3] L. F. Liotta, Appl. Catal. B, 2010, 100, 403-412.

[4] S. Scirè, L. F. Liotta, Appl. Catal. B, 2012, 125, 222-246.

[5] M. Ousmane, L. F. Liotta, G. Di Carlo, G. Pantaleo, A. M. Venezia, G.
Deganello, L. Retailleau, A. Boreave, A. Giroir-Fendler, Appl. Catal. $B$, 2011, 101, 629-637.

[6] J. J. Zhu, H. L. Li, L. Y. Zhong, P. Xiao, X. L. Xu, X. G. Yang, Z. Zhao, J. L. Li, ACS Catal., 2014, 4, 2917-2940.

[7] S. Irusta, M. P. Pina, M. Menéndez, J. Santamaría, J. Catal., 1998, $179,400-412$.

[8] J. M. Giraudon, A. Elhachimi, F. Wyrwalski, S. Siffert, A. Aboukaïs, J. F. Lamonier, G. Leclercq, Appl. Catal. B, 2007, 75, 157-166.

[9] Y. Lou, L. Wang, Z. Y. Zhao, Y. H. Zhang, Z. G. Zhang, G. Z. Lu, Y. Guo, Y. L. Guo, Appl. Catal. B, 2014, 146, 43-49.

[10] T. Cai, H. Huang, W. Deng, Q. G. Dai, W. Liu, X. Y. Wang, Appl. Catal. $B$, 2015, 166-167, 393-405.

[11] L. Y. Jin, R. H. Ma, J. J. Lin, L. Meng, Y. J. Wang, M. F. Luo, Ind Eng Chem Res, 2011, 50, 10878-10882.

[12] V. P. Santos, S. A. C. Carabineiro, P. B. Tavares, M. F. R. Pereira, J. J. M. Órfão, J. L. Figueiredo, Appl. Catal. B, 2010, 99, 198-205.

[13] S. C. Kim, W. G. Shim, Appl. Catal. B, 2009, 92, 429-436.

[14] M. Cargnello, V. V. T. Doan-Nguyen, T. R. Gordon, R. E. Diaz, E. A. Stach, R. J. Gorte, P. Fornasiero, C. B. Murray, Science, 2013, 341, 771-773.

[15] M. Cargnello, J. J. D. Jaén, J. C. H. Garrido, K. Bakhmutsky, T. Montini, J. J. Calvino Gámez, R. J. Gorte, P. Fornasiero, Science, 2012, 337, 713-717. 


\section{Graphical Abstract}

Chin. J. Catal., 2016, 37: 1193-1205 doi: 10.1016/S1872-2067(16)62457-9

Catalytic removal of volatile organic compounds using ordered porous transition metal oxide and supported noble metal catalysts

Yuxi Liu, Jiguang Deng, Shaohua Xie, Zhiwei Wang, Hongxing Dai* Beijing University of Technology

This review focused on recent advances in the synthesis of ordered porous transition metal oxides, perovskites, and supported noble metal catalysts and their catalytic oxidation of VOCs.

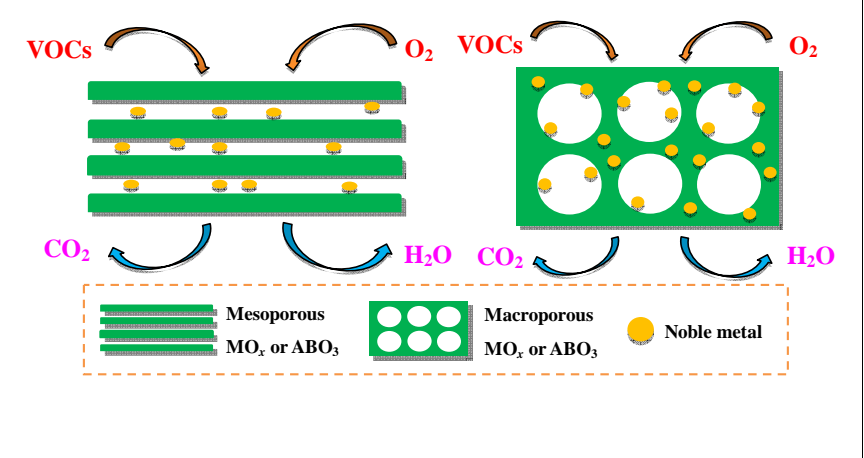

[16] E. J. Peterson, A. T. De La Riva, S. Lin, R. S. Johnson, H. Guo, J. T. Miller, J. H. Kwak, C. H. F. Peden, B. Kiefer, L. F. Allard, F. H. Ribeiro, A. K. Datye, Nat. Commun., 2014, 5, 4885.

[17] T. M. Onn, S. Y. Zhang, L. Arroyo-Ramirez, Y. C. Chung, G. W. Graham, X. Q. Pan, R. J. Gorte, ACS Catal., 2015, 5, 5696-5701.

[18] J. Xu, L. Ouyang, W. Mao, X. J. Yang, X. C. Xu, J. J. Su, T. Z. Zhuang, H. Li, Y. F. Han, ACS Catal., 2012, 2, 261-269.

[19] W. B. Li, J. X. Wang, H. Gong, Catal. Today, 2009, 148, 81-87.

[20] S. H. Liang, T. G. Xu, F. Teng, R. L. Zong, Y. F. Zhu, Appl. Catal. B, 2010, 96, 267-275.

[21] P. Ciambelli, S. Cimino, S. De Rossi, L. Lisi, G. Minelli, P. Porta, G. Russo, Appl. Catal. B, 2001, 29, 239-250.

[22] Y. Nishihata, J. Mizuki, T. Akao, H. Tanaka, M. Uenishi, M. Kimura, T. Okamoto, N. Hamada, Nature, 2002, 418, 164-167.

[23] H. Tanaka, M. Taniguchi, M. Uenishi, N. Kajita, I. Tan, Y. Nishihata, J. Mizuki, K. Narita, M. Kimura, K. Kaneko, Angew. Chem. Int. Ed., 2006, 45, 5998-6002.

[24] X. W. Xie, Y. Li, Z. Q. Liu, M. Haruta, W. J. Shen, Nature, 2009, 458, 746-749.

[25] H. Wang, C. L. Chen, Y. X. Zhang, L. X. Peng, S. Ma, T. Yang, H. H. Guo, Z. D. Zhang, D. S. Su, J. Zhang, Nat. Commun., 2015, 6, 7181.

[26] P. F. Zhang, H. F. Lu, Y. Zhou, L. Zhang, Z. L. Wu, S. Z. Yang, H. L. Shi, Q. L. Zhu, Y. F. Chen, S. Dai, Nat. Commun., 2015, 6, 8446.

[27] Y. B. Yu, T. Takei, H. Ohashi, H. He, X. L. Zhang, M. Haruta, J. Catal., 2009, 267, 121-128.

[28] J. Jansson, A. E. C. Palmqvist, E. Fridell, M. Skoglundh, L. Österlund, P. Thormählen, V. Langer, J. Catal., 2002, 211, 387-397.

[29] J. G. Deng, S. N. He, S. H. Xie, H. G. Yang, Y. X. Liu, G. S. Guo, H. X. Dai, Environ. Sci. Technol., 2015, 49, 11089-11095.

[30] Y. J. Feng, L. Li, S. F. Niu, Y. Qu, Q. Zhang, Y. S. Li, W. R. Zhao, H. Li, J. L. Shi, Appl. Catal. B, 2012, 111-112, 461-466.

[31] K. S. W. Sing, D. H. Everett, R. A. W. Haul, L. Moscou, R. A. Pierotti, J. Rouquérol, T. Siemieniewska, Pure Appl. Chem., 1985, 57, 603-619.

[32] A. H. Lu, F. Schüth, C. R. Chim, 2005, 8, 609-620.

[33] T. Valdés-Solís, A. B. Fuertes, Mater. Res. Bull., 2006, 41, 2187-2197.

[34] K. K. Zhu, B. Yue, W. Z. Zhou, H. Y. He, Chem. Commun., 2003, 98-99.

[35] B. Z. Tian, X. Y. Liu, H. F. Yang, S. H. Xie, C. Z. Yu, B. Tu, D. Y. Zhao, Adv. Mater., 2003, 15, 1370-1374.

[36] S. C. Laha, R. Ryoo, Chem. Commun., 2003, 2138-2139.

[37] X. H. Sun, Y. F. Shi, P. Zhang, C. M. Zheng, X. Y. Zheng, F. Zhang, Y. C. Zhang, N. J. Guan, D. Y. Zhao, G. D. Stucky, J. Am. Chem. Soc., 2011, 133, 14542-14545.

[38] N. D. Petkovich, A. Stein, Chem. Soc. Rev., 2013, 42, 3721-3739.
[39] A. Stein, R. C. Schroden, Curr. Opin. Solid. S. T. M., 2001, 5, 553-564.

[40] M. Sadakane, T. Asanuma, J. Kubo, W. Ueda, Chem. Mater., 2005, 17, 3546-3551.

[41] M. Sadakane, T. Horiuchi, N. Kato, C. Takahashi, W. Ueda, Chem. Mater., 2007, 19, 5779-5785.

[42] Y. N. Kim, S. J. Kim, E. K. Lee, E. O. Chi, N. H. Hur, C. S. Hong, J. Mater. Chem., 2004, 14, 1774-1777.

[43] Y. C. Wei, J. Liu, Z. Zhao, Y. S. Chen, C. M. Xu, A. J. Duan, G. Y. Jiang, H. He, Angew. Chem. Int. Ed., 2011, 50, 2326-2329.

[44] Y. C. Wei, J. Liu, Z. Zhao, A. J. Duan, G. Y. Jiang, C. M. Xu, J. S. Gao, H. He, X. P. Wang, Energy Environ. Sci., 2011, 4, 2959-2970.

[45] J. F. Xu, J. Liu, Z. Zhao, J. X. Zheng, G. Z. Zhang, A. J. Duan, G. Y. Jiang, Catal. Today, 2010, 153, 136-142.

[46] G. M. Bai, H. X. Dai, J. G. Deng, Y. X. Liu, F. Wang, Z. X. Zhao, W. G. Qiu, C. T. Au, Appl. Catal. A, 2013, 450, 42-49.

[47] Y. S. Xia, H. X. Dai, H. Y. Jiang, L. Zhang, Catal. Commun., 2010, 11, 1171-1175.

[48] J. G. Deng, L. Zhang, H. X. Dai, Y. S. Xia, H. Y. Jiang, H. Zhang, H. He, J. Phys. Chem. C, 2010, 114, 2694-2700.

[49] Y. S. Xia, H. X. Dai, H. Y. Jiang, J. G. Deng, H. He, C. T. Au, Environ. Sci. Technol., 2009, 43, 8355-8360.

[50] Y. S. Xia, H. X. Dai, L. Zhang, J. G. Deng, H. He, C. T. Au, Appl. Catal. B, 2010, 100, 229-237.

[51] Y. S. Xia, H. X. Dai, H. Y. Jiang, L. Zhang, J. G. Deng, Y. X. Liu, J. Hazard Mater., 2011, 186, 84-91.

[52] H. N. Li, L. Zhang, H. X. Dai, H. He, Inorg. Chem., 2009, 48, 4421-4434.

[53] Y. X. Liu, H. X. Dai, Y. C. Du, J. G. Deng, L. Zhang, Z. X. Zhao, C. T. Au, J. Catal., 2012, 287, 149-160.

[54] Y. X. Liu, H. X. Dai, Y. C. Du, J. G. Deng, L. Zhang, Z. X. Zhao, Appl. Catal. B, 2012, 119-120, 20-31.

[55] Y. X. Liu, H. X. Dai, J. G. Deng, L. Zhang, B. Z. Gao, Y. Wang, X. W. Li, S. H. Xie, G. S. Guo, Appl. Catal. B, 2013, 140-141, 317-326.

[56] X. W. Li, H. X. Dai, J. G. Deng, Y. X. Liu, S. H. Xie, Z. X. Zhao, Y. Wang, G. S. Guo, H. Arandiyan, Chem. Eng. J., 2013, 228, 965-975.

[57] J. Yuan, H. X. Dai, L. Zhang, J. G. Deng, Y. X. Liu, H. Zhang, H. Y. Jiang, H. He, Catal. Today, 2011, 175, 209-215.

[58] Y. Wang, H. X. Dai, J. G. Deng, Y. X. Liu, Z. X. Zhao, X. W. Li, H. Arandiyan, Chem. Eng. J., 2013, 226, 87-94.

[59] K. M. Ji, H. X. Dai, J. X. Dai, J. G. Deng, F. Wang, H. Zhang, L. Zhang, Catal. Today, 2013, 201, 40-48.

[60] Y. X. Liu, H. X. Dai, J. G. Deng, L. Zhang, C. T. Au, Nanoscale, 2012, 4, 2317-2325.

[61] J. G. Deng, L. Zhang, H. X. Dai, C. T. Au, Appl. Catal. A, 2009, 352, 43-49. 
[62] R. D. Zhang, P. X. Li, N. Liu, W. R. Yue, B. H. Chen, J. Mater. Chem. A, 2014, 2, 17329-17340.

[63] S. M. Vickers, R. Gholami, K. J. Smith, M. J. MacLachlan, ACS Appl. Mater. Interfaces, 2015, 7, 11460-11466.

[64] B. Y. Bai, J. H. Li, J. M. Hao, Appl. Catal. B, 2015, 164, 241-250.

[65] B. Puertolas, B. Solsona, S. Agouram, R. Murillo, A. M. Mastral, A. Aranda, S. H. Taylor, T. Garcia, Appl. Catal. B, 2010, 93, 395-405.

[66] T. Garcia, S. Agouram, J. F. Sánchez-Royod, R. Murillo, A. M. Mastral, A. Aranda, I. Vázquez, A. Dejoz, B. Solsona, Appl. Catal. A, 2010, 386, 16-27.

[67] S. J. Sun, Q. M. Gao, H. L. Wang, J. K. Zhu, H. L. Guo, Appl. Catal. B, 2010, 97, 284-291.

[68] Y. Ren, Z. Ma, L. P. Qian, S. Dai, H. Y. He, P. G. Bruce, Catal. Lett, 2009, 131, 146-154.

[69] Y. B. Yu, T. Takei, H. Ohashi, H. He, X. L. Zhang, M. Haruta, J. Catal., 2009, 267, 121-128.

[70] Y. C. Du, Q. Meng, J. S. Wang, J. Yan, H. G. Fan, Y. X. Liu, H. X. Dai, Microporous Mesoporous Mater., 2012, 162, 199-206.

[71] D. Gu, C. J. Jia, C. Weidenthaler, H. J. Bongard, B. Spliethoff, W. Schmidt, F. Schüth, J. Am. Chem. Soc., 2015, 137, 11407-11418.

[72] M. M. Nair, H. Yen, F. Kleitz, C. R. Chim, 2014, 17, 641-655.

[73] H. Yen, Y. Seo, S. Kaliaguine, F. Kleitz, Angew. Chem. Int. Ed., 2012, 51, 12032-12035.

[74] C. He, Y. K. Yu, C. W. Chen, L. Yue, N. L. Qiao, Q. Shen, J. S. Chen, Z. P. Hao, RSC Adv., 2013, 3, 19639-19656.

[75] N. Labhasetwar, G. Saravanan, S. K. Megarajan, N. Manwar, R. Khobragade, P. Doggali, F. Grasset, Sci. Technol. Adv. Mater., 2015, $16,1-13$.

[76] Y. G. Wang, J. W. Ren, Y. Q. Wang, F. Y. Zhang, X. H. Liu, Y. Guo, G. Z. Lu, J. Phys. Chem. C, 2008, 112, 15293-15298.

[77] M. M. Nair, F. Kleitz, S. Kaliaguine, ChemCatChem, 2012, 4, 387-394.

[78] B. Z. Gao, J. G. Deng, Y. X. Liu, Z. X. Zhao, X. W. Li, Y. Wang, H. X. Dai, Chin. J. Catal., 2013, 34, 2223-2229.

[79] A. T. Bell, Science, 2003, 299, 1688-1691.

[80] X. Q. Yan, X. J. Wang, Y. Tang, G. C. Ma, S. H. Zou, R. H. Li, X. G. Peng, S. Dai, J. Fan, Chem. Mater., 2013, 25, 1556-1563.

[81] G. Ma, A. Binder, M. F. Chi, C. Liu, R. C. Jin, D. E. Jiang, J. Fan, S. Dai, Chem. Commun., 2012, 48, 11413-11415.

[82] H. J. Wu, G. Pantaleo, A. M. Venezia, L. F. Liotta, Catalysts, 2013, 3, 774-793.

[83] C. Y. Ma, Z. Mu, J. J. Li, Y. G. Jin, J. Cheng, G. Q. Lu, Z. P. Hao, S. Z. Qiao, J. Am. Chem. Soc., 2010, 132, 2608-2613.

[84] C. Y. Ma, D. H. Wang, W. J. Xue, B. J. Dou, H. L. Wang, Z. P. Hao, Environ. Sci. Technol., 2011, 45, 3628-3634.

[85] B. Y. Bai, J. H. Li, ACS Catal., 2014, 4, 2753-2762.

[86] K. An, S. Alayoglu, N. Musselwhite, S. Plamthottam, G. Melaet, A. E. Lindeman, G. A. Somorjai, J. Am. Chem. Soc., 2013, 135, 16689-16696.

[87] T. Barakat, J. C. Rooke, E. Genty, R. Cousin, S. Siffert, B. L. Su, Energy Environ. Sci., 2013, 6, 371-391.

[88] Y. X. Liu, H. X. Dai, J. G. Deng, S. H. Xie, H. G. Yang, W. Tan, W. Han, Y. Jiang, G. S. Guo, J. Catal., 2014, 309, 408-418.

[89] Q. Ye, J. S. Zhao, F. F. Huo, D. Wang, S. Y. Cheng, T. F. Kang, H. X. Dai, Microporous Mesoporous Mater., 2013, 172, 20-29.

[90] Y. F. Wang, C. B. Zhang, F. D. Liu, H. He, Appl. Catal. B, 2013, 142-143, 72-79.

[91] Y. F. Wang, C. B. Zhang, Y. B. Yu, R. L. Yue, H. He, Catal. Today, 2015, 242, 294-299.

[92] M. S. Jin, J. N. Park, J. K. Shon, J. H. Kim, Z. H. Li, Y. K. Park, J. M. Kim, Catal. Today, 2012, 185, 183-190.

[93] C. He, L. L. Xu, L. Yue, Y. T. Chen, J. S. Chen, Z. P. Hao, Ind. Eng. Chem.
Res., 2012, 51, 7211-7222.

[94] S. G. Rudisill, N. M. Hein, D. Terzic, A. Stein, Chem. Mater., 2013, $25,745-753$.

[95] A. Stein, B. E. Wilson, S. G. Rudisill, Chem. Soc. Rev., 2013, 42, 2763-2803.

[96] J. G. Deng, L. Zhang, H. X. Dai, H. He, C. T. Au, Ind. Eng. Chem. Res., 2008, 47, 8175-8183.

[97] P. Ciambelli, S. Cimino, S. D. Rossi, M. Faticanti, L. Lisi, G. Minelli, I. Pettiti, P. Porta, G. Russo, M. Turco, Appl. Catal. B, 2000, 24, 243-253.

[98] A. Machocki, T. Ioannides, B. Stasinska, W. Gac, G. Avgouropoulos, D. Delimaris, W. Grzegorczyk, S. Pasieczna, J. Catal., 2004, 227, 282-296.

[99] J. N. Kuhn, U. S. Ozkan, J. Catal., 2008, 253, 200-211.

[100] H. Arandiyan, H. X. Dai, J. G. Deng, Y. X. Liu, B. Y. Bai, Y. Wang, X. W. Li, S. H. Xie, J. H. Li, J. Catal., 2013, 307, 327-339.

[101] R. Z. Zhang, H. X. Dai, Y. C. Du, L. Zhang, J. G. Deng, Y. S. Xia, Z. X. Zhao, X. Meng, Y. X. Liu, Inorg. Chem., 2011, 50, 2534-2544.

[102] Y. J. Zhang, J. G. Deng, H. Zhang, Y. X. Liu, H. X. Dai, Catal. Today, 2015, 245, 28-36.

[103] J. Yuan, H. X. Dai, L. Zhang, J. G. Deng, Y. X. Liu, H. Zhang, H. Y. Jiang, H. He, Catal. Today, 2011, 175, 209-215.

[104] Z. X. Zhao, H. X. Dai, J. G. Deng, Y. C. Du, Y. X. Liu, L. Zhang, Microporous Mesoporous Mater., 2012, 163, 131-139.

[105] K. M. Ji, H. X. Dai, J. G. Deng, L. Zhang, F. Wang, H. Y. Jiang, C. T. Au, Appl. Catal. A, 2012, 425-426, 153-160.

[106] Z. X. Zhao, H. X. Dai, J. G. Deng, Y. C. Du, Y. X. Liu, L. Zhang, J. Mol. Catal. A, 2013, 366, 116-125.

[107] W. Z. Si, Y. Wang, Y. Peng, J. H. Li, Angew. Chem. Int. Ed., 2015, 54, 7954-7957.

[108] F. Wyrwalski, J. F. Lamonier, S. Siffert, A. Aboukaïs, Appl. Catal. B, 2007, 70, 393-399.

[109] Z. K. Zhao, X. L. Lin, R. H. Jin, G. R. Wang, T. Muhammad, Appl. Catal. B, 2012, 115-116, 53-62.

[110] A. P. Jia, G. S. Hu, L. Meng, Y. L. Xie, J. Q. Lu, M. F. Luo, J. Catal,, 2012, 289, 199-209.

[111] K. M. Ji, H. X. Dai, J. G. Deng, L. Y. Song, B. Z. Gao, Y. Wang, X. W. Li, Appl. Catal. B, 2013, 129, 539-548.

[112] Y. X. Liu, H. X. Dai, J. G. Deng, Y. C. Du, X. W. Li, Z. X. Zhao, Y. Wang, B. Z. Gao, H. G. Yang, G. S. Guo, Appl. Catal. B, 2013, 140-141, 493-505.

[113] I. X. Green, W. J. Tang, M. Neurock, J. T. Yates, Science, 2011, 333, 736-739.

[114] Q. Fu, W. X. Li, Y. X. Yao, H. Y. Liu, H. Y. Su, D. Ma, X. K. Gu, L. M. Chen, Z. Wang, H. Zhang, W. Bing, X. H. Bao, Science, 2010, 328, 1141-1144.

[115] J. Zhang, Y. Jin, C. Y. Li, Y. N. Shen, L. Han, Z. X. Hua, X. W. Di, Z. L. Liu, Appl. Catal. B, 2009, 91, 11-20.

[116] B. C. Liu, C. Y. Li, Y. F. Zhang, Y. Liu, W. T. Hu, Q. Wang, L. Han, J. Zhang, Appl. Catal. B, 2012, 111-112, 467-475.

[117] Y. X. Liu, H. X. Dai, J. G. Deng, X. W. Li, Y. Wang, H. Arandiyan, S. H. Xie, H. G. Yang, G. S. Guo, J. Catal., 2013, 305, 146-153.

[118] H. Arandiyan, H. X. Dai, K. M. Ji, H. Y. Sun, J. H. Li, ACS Catal., 2015, 5, 1781-1793.

[119] H. Arandiyan, H. X. Dai, K. M. Ji, H. Y. Sun, Y. Y. Zhao, J. H. Li, Small, 2015, 11, 2366-2371.

[120] S. H. Xie, H. X. Dai, J. G. Deng, Y. X. Liu, H. G. Yang, Y. Jiang, W. Tan, A. S. Ao, G. S. Guo, Nanoscale, 2013, 5, 11207-11219.

[121] X. W. Li, H. X. Dai, J. G. Deng, Y. X. Liu, S. H. Xie, Z. X. Zhao, Y. Wang, G. S. Guo, H. Arandiyan, Chem. Eng. J., 2013, 228, 965-975.

[122] H. Arandiyan, H. X. Dai, J. G. Deng, Y. Wang, H. Y. Sun, S. H. Xie, B. Y. Bai, Y. X. Liu, K. M. Ji, J. H. Li, J. Phys. Chem. C, 2014, 118, 
14913-14928.

[123] Y. Jiang, J. G. Deng, S. H. Xie, H. G. Yang, H. X. Dai, Ind. Eng. Chem. Res., 2015, 54, 900-910.

[124] S. H. Xie, H. X. Dai, J. G. Deng, H. G. Yang, W. Han, H. Arandiyan, G. S. Guo, J. Hazard Mater., 2014, 279, 392-401.

[125] D. S. Wang, Q. Peng, Y. D. Li, Nano Res., 2010, 3, 574-80.
[126] S. H. Xie, J. G. Deng, S. M. Zang, H. G. Yang, G. S. Guo, H. Arandiyan, H. X. Dai, J. Catal., 2015, 322, 38-48.

[127] Z. X. Wu, J. G. Deng, Y. X. Liu, S. H. Xie, Y. Jiang, X. T. Zhao, J. Yang, H. Arandiyan, G. S. Guo, H. X. Dai, J. Catal., 2015, 332, 13-24.

[128] Y. X. Liu, B. C. Liu, Y. Liu, Q. Wang, W. T. Hu, P. Jing, L. X. Liu, S. L. Yu, J. Zhang, Appl. Catal. B, 2013, 142-143, 615-625.

\title{
有序多孔过渡金属氧化物及其负载贵金属催化剂对挥发性有机物氧化的催化性能
}

\author{
刘雨溪, 邓积光, 谢少华, 王治伟, 戴洪兴* \\ 北京工业大学环境与能源工程学院化学化工系, 绿色催化与分离北京市重点实验室, 区域大气污染控制北京市重点实验室, \\ 新型功能材料教育部重点实验室, 催化化学与纳米科学研究室, 北京 100124
}

摘要: 大部分的挥发性有机物 (VOCs) 污染环境, 危害人身健康. 目前, 我国虽然已开展了治理 VOCs 污染的工作, 但还缺 乏有效的、拥有自主知识产权的 VOCs 治理技术, 因此研发新型高效 VOCs 处理技术迫在眉睫. 催化氧化法是公认的最有 效消除 VOCs 的途径之一, 而高性能催化剂的研发是实现该过程的关键. 近年来, 人们围绕消除 VOCs 的高效且价廉的催 化剂的研发开展了卓有成效的工作, 许多过渡金属氧化物、混合或复合金属氧化物及其负载贵金属催化剂均被认为是有效 的催化氧化材料. 与体相材料相比, 多孔材料具有发达的孔道结构和高的比表面积, 一方面有利于反应物的扩散、吸附和 脱附, 因而具有更高的催化活性和选择性; 另一方面有利于活性组分 (如贵金属等) 在多孔材料表面的高分散, 抑制活性组 分的烧结, 因而具有更好的催化稳定性.

本文简述了近年来多孔金属氧化物在环境污染物消除领域的研究进展, 阐述了以有序介孔或大孔过渡金属氧化物、钲 钠矿型氧化物和负载贵金属催化剂的制备及其对典型 VOCs(如苯系物、醇类、醛类及酮类等) 氧化的催化性能, 重点介绍 了四类催化材料, 包括有序介孔过渡金属氧化物或复合氧化物 $\left(\mathrm{Co}_{3} \mathrm{O}_{4}, \mathrm{MnO}_{2}, \mathrm{Fe}_{2} \mathrm{O}_{3}, \mathrm{Cr}_{2} \mathrm{O}_{3}\right.$ 和 $\mathrm{LaFeO}_{3}$ 等) 催化剂, 有序介孔 金属氧化物负载贵金属 $\left(\mathrm{Au} / \mathrm{Co}_{3} \mathrm{O}_{4}, \mathrm{Au} / \mathrm{MnO}_{2}\right.$ 和 $\mathrm{Pd} / \mathrm{Co}_{3} \mathrm{O}_{4}$ 等) 催化剂, 三维有序大孔过渡金属氧化物或复合氧化物 $\left(\mathrm{Fe}_{2} \mathrm{O}_{3}\right.$, $\mathrm{LaMnO}_{3}, \mathrm{La}_{0.6} \mathrm{Sr}_{0.4} \mathrm{MnO}_{3}$ 和 $\mathrm{La}_{2} \mathrm{CuO}_{4}$ 等) 催化剂, 以及三维有序大孔金属氧化物负载贵金属 $\left(\mathrm{Au} / \mathrm{Co}_{3} \mathrm{O}_{4}, \mathrm{Au} / \mathrm{LaCoO}_{3}\right.$, $\mathrm{Au} / \mathrm{La}_{0.6} \mathrm{Sr}_{0.4} \mathrm{MnO}_{3}$ 和 $\mathrm{AuPd} / \mathrm{Co}_{3} \mathrm{O}_{4}$ 等) 催化剂的制备及其物化性质与对苯、甲苯、二甲苯、乙醇、丙酮、甲醛、甲烷或氯甲 烷等 VOCs 氧化的催化性能之间的相关性.

借助二氧化硅或聚甲基丙烯酸甲酯微球等硬模板, 采用纳米浇铸法可制备出二维或三维的有序单一或多级孔道结构 的金属氧化物. 研究表明, 多孔金属氧化物的催化性能远优于其体相甚至纳米催化剂的. 有序多孔材料的优异催化性能与 其拥有大的比表面积、高的吸附氧物种浓度、优良的低温还原性、独特的孔道结构、活性组分的高分散以及贵金属与氧 化物载体之间的强相互作用等有关. 探明影响催化剂活性的因素有利于从原子水平上认识催化过程, 为新型高效催化剂 的设计与制备奠定基础.

本文还指出了此类研究中存在的一些问题, 例如利用硬模板法制备多孔材料的缺点是目标催化剂的收率低, 硬模板浪 费严重, 大规模制备多孔催化剂势必增加制备成本, 这些问题有待于妥善解决. 与此同时, 还展望了 VOCs 消除技术的未 来发展趋势, 采用多种技术联用的方法有望最大程度地提高 VOCs 的消除效率.

关键词: 挥发性有机物; 催化燃烧; 多孔过渡金属氧化物; 钻钛矿型氧化物; 负载贵金属催化剂

收稿日期: 2016-03-31. 接受日期: 2016-05-03. 出版日期: 2016-08-05.

*通讯联系人. 电话: (010)67396118; 传真: (010)67391983; 电子信箱: hxdai@bjut.edu.cn

基金来源: 国家高技术研究发展计划 (863 计划, 2015AA034603); 国家自然科学基金 (21377008, 201077007, 20973017); 北京市 高校创新团队推进计划; 科研基地建设-科技创新平台-国家材料研究基地建设.

本文的英文电子版由Elsevier出版社在ScienceDirect上出版(http://www.sciencedirect.com/science/journal/18722067). 